Western University

Scholarship@Western

Surgery Publications

Surgery Department

2007

\title{
Cholecystectomy Deferral in Patients with Endoscopic Sphincterotomy
}

Vivian McAlister

University of Western Ontario, vmcalist@uwo.ca

Eric Davenport

University of Western Ontario, edavenpo@uwo.ca

Elizabeth Renouf

University of Western Ontario, erenouf@uwo.ca

Follow this and additional works at: https://ir.lib.uwo.ca/surgerypub

Part of the Statistics and Probability Commons, and the Surgery Commons

Citation of this paper:

McAlister, Vivian; Davenport, Eric; and Renouf, Elizabeth, "Cholecystectomy Deferral in Patients with Endoscopic Sphincterotomy" (2007). Surgery Publications. 28.

https://ir.lib.uwo.ca/surgerypub/28 


\title{
Cholecystectomy deferral in patients with endoscopic sphincterotomy (Review)
}

\author{
McAlister V, Davenport E, Renouf E
}

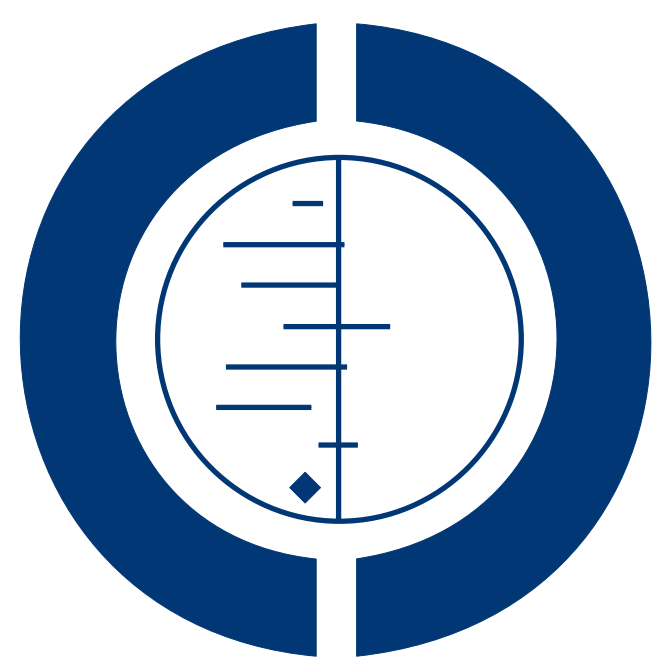

\section{THE COCHRANE COLLABORATION $^{\circledR}$}

This is a reprint of a Cochrane review, prepared and maintained by The Cochrane Collaboration and published in The Cochrane Library 2009, Issue 1

http://www.thecochranelibrary.com

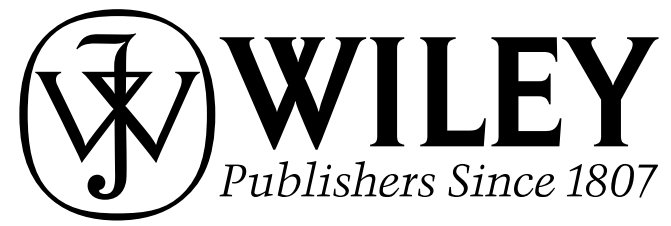

Cholecystectomy deferral in patients with endoscopic sphincterotomy (Review)

Copyright (C) 2009 The Cochrane Collaboration. Published by John Wiley \& Sons, Ltd. 
TABLE OF CONTENTS

HEADER . . . . . . . . . . . . . . . . . . . . . . . . . . . . . . . . . . . . . . .

ABSTRACT . . . . . . . . . . . . . . . . . . . . . . . . . . . . . . . . . . . . . . . . . . 1

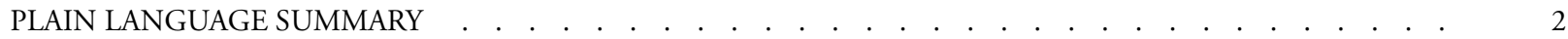

BACKGROUND . . . . . . . . . . . . . . . . . . . . . . . . . . . . . . . . . . . . 2

OBJECTIVES . . . . . . . . . . . . . . . . . . . . . . . . . . . . . . . . . . . . . 3

METHODS . . . . . . . . . . . . . . . . . . . . . . . . . . . . . . . . . . . . . .

RESULTS . . . . . . . . . . . . . . . . . . . . . . . . . . . . . . . . . . . . . . . . . . . 44

DISCUSSION . . . . . . . . . . . . . . . . . . . . . . . . . . . . . . . . 6

AUTHORS' CONCLUSIONS . . . . . . . . . . . . . . . . . . . . . . . . . . . . . . . . . . 7

ACKNOWLEDGEMENTS . . . . . . . . . . . . . . . . . . . . . . . . . . . . . . . . . . . . . . . . . . . . 7

REFERENCES . . . . . . . . . . . . . . . . . . . . . . . . . . . . . . . . . . . . . . . . . 7

CHARACTERISTICS OF STUDIES . . . . . . . . . . . . . . . . . . . . . . . . . . . . . 8

DATA AND ANALYSES . . . . . . . . . . . . . . . . . . . . . . . . . . . . . . . . . . . . . . . . . . . . $\quad 14$

Analysis 1.1. Comparison 1 Wait-and-see versus prophylactic cholecystectomy, Outcome 1 Mortality. . . . . . . 17

Analysis 1.2. Comparison 1 Wait-and-see versus prophylactic cholecystectomy, Outcome 2 Biliary pain or cholecystitis. 17

Analysis 1.3. Comparison 1 Wait-and-see versus prophylactic cholecystectomy, Outcome 3 Pancreatitis. . . . . . 18

Analysis 1.4. Comparison 1 Wait-and-see versus prophylactic cholecystectomy, Outcome 4 Recurrent jaundice or cholangitis. . . . . . . . . . . . . . . . . . . . . . . . . . . . . . . . . . . . 19

Analysis 1.5. Comparison 1 Wait-and-see versus prophylactic cholecystectomy, Outcome 5 Major adverse events. . . 20

Analysis 1.6. Comparison 1 Wait-and-see versus prophylactic cholecystectomy, Outcome 6 Minor adverse events. . $\quad 21$

Analysis 1.7. Comparison 1 Wait-and-see versus prophylactic cholecystectomy, Outcome 7 Additional cholangiography

(ERCP or PTC). . . . . . . . . . . . . . . . . . . . . . . . . . . . . . . . . . . 22

Analysis 1.8. Comparison 1 Wait-and-see versus prophylactic cholecystectomy, Outcome 8 Difficult cholecystectomy. 23

Analysis 2.1. Comparison 2 Stratified by method of cholecystectomy, Outcome 1 Mortality. . . . . . . . . . . . 24

Analysis 2.2. Comparison 2 Stratified by method of cholecystectomy, Outcome 2 Biliary pain or cholecystitis. . . . 25

Analysis 2.3. Comparison 2 Stratified by method of cholecystectomy, Outcome 3 Pancreatitis. . . . . . . . . . . 26

Analysis 2.4. Comparison 2 Stratified by method of cholecystectomy, Outcome 4 Recurrent jaundice or cholangitis. . 27

Analysis 2.5. Comparison 2 Stratified by method of cholecystectomy, Outcome 5 Major adverse events. . . . . . . 28

Analysis 2.6. Comparison 2 Stratified by method of cholecystectomy, Outcome 6 Minor adverse events. . . . . . . 29

Analysis 2.7. Comparison 2 Stratified by method of cholecystectomy, Outcome 7 Additional cholangiography (ERCP or PTC).

Analysis 2.8. Comparison 2 Stratified by method of cholecystectomy, Outcome 8 Difficult cholecystectomy. . . . . 31

Analysis 3.1. Comparison 3 Stratified by patient ASA class, Outcome 1 Mortality. . . . . . . . . . . . . . . . . 32

Analysis 3.2. Comparison 3 Stratified by patient ASA class, Outcome 2 Biliary pain or cholecystitis. . . . . . . . . 33

Analysis 3.3. Comparison 3 Stratified by patient ASA class, Outcome 3 Pancreatitis. . . . . . . . . . . . . . . . 34

Analysis 3.4. Comparison 3 Stratified by patient ASA class, Outcome 4 Recurrent jaundice or cholangitis. . . . . . 35

Analysis 3.5. Comparison 3 Stratified by patient ASA class, Outcome 5 Major adverse events. . . . . . . . . . . . 36

Analysis 3.6. Comparison 3 Stratified by patient ASA class, Outcome 6 Minor adverse events. . . . . . . . . . . . 37

Analysis 3.7. Comparison 3 Stratified by patient ASA class, Outcome 7 Additional cholangiography (ERCP or PTC). 38

Analysis 3.8. Comparison 3 Stratified by patient ASA class, Outcome 8 Difficult cholecystectomy. . . . . . . . . 39

APPENDICES . . . . . . . . . . . . . . . . . . . . . . . . . . . . . . . . . . . . . 39

WHAT'S NEW . . . . . . . . . . . . . . . . . . . . . . . . . . . . . . . . . . . . . 41

HISTORY . . . . . . . . . . . . . . . . . . . . . . . . . . . . . . . . . . . 41

CONTRIBUTIONS OF AUTHORS . . . . . . . . . . . . . . . . . . . . . . . . . . . . . . . . . . . . . . 41

DECLARATIONS OF INTEREST . . . . . . . . . . . . . . . . . . . . . . . . . . . . . . . . . . . . . . . . . . . 4.41

SOURCES OF SUPPORT . . . . . . . . . . . . . . . . . . . . . . . . . . . . . . . . . . . . . . . . . . 41

INDEX TERMS . . . . . . . . . . . . . . . . . . . . . . . . . . . . . . . . . . 41

Cholecystectomy deferral in patients with endoscopic sphincterotomy (Review)

Copyright @ 2009 The Cochrane Collaboration. Published by John Wiley \& Sons, Ltd. 


\title{
[Intervention Review]
}

\section{Cholecystectomy deferral in patients with endoscopic sphincterotomy}

\author{
Vivian McAlister ${ }^{1}$, Eric Davenport ${ }^{2}$, Elizabeth Renouf ${ }^{3}$ \\ ${ }^{1} 1$ Canadian Field Hospital, Canadian Forces, London, Canada. ${ }^{2}$ Surgery, Division of General Surgery, University of Western Ontario, \\ London, Canada. ${ }^{3}$ London, Canada
}

Contact address: Vivian McAlister, 1 Canadian Field Hospital, Canadian Forces, C4-212, University Hospital, London, Ontario, N6A 5A5, Canada.vmcalist@uwo.ca.

Editorial group: Cochrane Hepato-Biliary Group.

Publication status and date: Edited (no change to conclusions), published in Issue 1, 2009.

Review content assessed as up-to-date: 27 July 2007.

Citation: McAlister V, Davenport E, Renouf E. Cholecystectomy deferral in patients with endoscopic sphincterotomy. Cochrane Database of Systematic Reviews 2007, Issue 4. Art. No.: CD006233. DOI: 10.1002/14651858.CD006233.pub2.

Copyright (c) 2009 The Cochrane Collaboration. Published by John Wiley \& Sons, Ltd.

\begin{abstract}
A B S T R A C T
Background

Cholecystectomy is not required in up to $64 \%$ of patients who adopt a wait-and-see policy after endoscopic clearance of common bile duct stones. Although reports of retrospective cohort series have shown a higher mortality among patients who defer cholecystectomy, it is not known if this is due to the patients' premorbid health status or due to the deferral of cholecystectomy. Randomised clinical trials of prophylactic cholecystectomy versus wait-and-see have not had sufficient power to demonstrate differences in survival.
\end{abstract}

\section{Objectives}

To evaluate the beneficial and harmful effects of cholecystectomy deferral (wait-and-see) versus elective (prophylactic) cholecystectomy in patients who have had an endoscopic biliary sphincterotomy.

\section{Search strategy}

We searched The Cochrane Hepato-Biliary Group Controlled Trials Register, the Cochrane Controlled Trials Register (CENTRAL) in The Cochrane Library, MEDLINE (1966 to 2007), EMBASE (1980 to 2007), and Science Citation Index Expanded without language restrictions until April 2007.

\section{Selection criteria}

Randomised clinical trials comparing patients whose gallbladder was left in-situ after endoscopic sphincterotomy (wait-and-see group) versus patients who had cholecystectomy with either endoscopic sphincterotomy or common bile duct exploration (prophylactic cholecystectomy group), irrespective of blinding, language, or publication status.

\section{Data collection and analysis}

We assessed the impact of a wait-and-see policy on mortality. Secondary outcomes assessed were the incidence of biliary pain, cholangitis, pancreatitis, need for cholangiography, need for cholecystectomy, and the rate of difficult cholecystectomy. We pooled data using relative risk with fixed-effect and random-effects models. 


\section{Main results}

We included 5 randomised trials with 662 participants out of 93 publications identified through the literature searches. The number of deaths was 47 in the wait-and-see group (334 patients) compared to 26 in the prophylactic cholecystectomy group (328 patients) for a $78 \%$ increased risk of mortality (RR $1.78,95 \%$ CI 1.15 to $2.75, \mathrm{P}=0.010)$. The survival benefit of prophylactic cholecystectomy was independent of trial design, inclusion of high risk patients or inclusion of any one of the five trials. Patients in the wait-and-see group had higher rates of recurrent biliary pain (RR 14.56, 95\% CI 4.95 to 42.78, P < 00001), jaundice or cholangitis (RR 2.53, 95\% CI 1.09 to $5.87, \mathrm{P}=0.03$ ), and of repeat ERCP or other forms of cholangiography (RR 2.36, 95\% CI 1.29 to $4.32, \mathrm{P}=0.005$ ). Cholecystectomy was eventually performed in $35 \%$ (115 patients) of the wait-and-see group.

\section{Authors' conclusions}

Prophylactic cholecystectomy should be offered to patients whose gallbladders remain in-situ after endoscopic sphincterotomy and common bile duct clearance.

\section{PLAIN LANGUAGE SUMMARY}

Prophylactic cholecystectomy should be offered to patients whose gallbladders remain in-situ after endoscopic sphincterotomy and common bile duct clearance

Surgical removal of the gallbladder is done routinely. Stones in the common bile duct usually come from the gallbladder and can be harmful. The usual treatment for gallstones that are in the common bile duct is endoscopic retrograde cholangiopancreatography (ERCP) and sphincterotomy. ERCP is an endoscopic procedure to remove stones from the common bile duct. More stones may enter the common bile duct from the gallbladder but it is not clear if the gallbladder should be removed preventively (prophylactic cholecystectomy) or if a wait-and-see policy (cholecystectomy deferral) would be better. We included 5 randomised trials with 662 participants out of 93 publications identified through the literature searches. The number of deaths was 47 in the wait-and-see group (334 patients) compared with 26 in the prophylactic cholecystectomy group (328 patients). This review of randomised clinical trials suggests that early removal of the gallbladder decreases the risk of death or of complications from gallstones. The number of patients (662) reviewed in this report prevents some of the subgroup analyses from being conclusive. Further clinical trials, particularly of highrisk patients, would solve this problem.

\section{B A C K G R O U N D}

Prior to the development of endoscopic retrograde cholangiopancreatography (ERCP) the treatment of choledocholithiasis-related illness was open cholecystectomy and common bile duct exploration if operative cholangiography confirmed the presence of residual stones in the bile duct. ERCP permits removal of biliary stones without open operation. The importance of its role in the management of choledocholithiasis increased with the development of the laparoscopic approach to cholecystectomy, which initially limited surgical access for common duct exploration (NIH 1992). Patients with suspected choledocholithiasis were advised to undergo ERCP and endoscopic biliary sphincterotomy before laparoscopic cholecystectomy was considered (Roy 1993; NIH 2002). The role of ductal pressure in biliary symptoms suggests that some patients may be managed by sphincterotomy alone because it reduces pressure in the biliary tree. Deferral of cholecystectomy after endoscopic sphincterotomy for choledocholithiasis in high-risk patients was first reported almost twenty-five years ago (Escourrou 1984). Only 13\% of 224 patients followed for three years required cholecystectomy. Currently, deferral of cholecystectomy (also known as wait-and-see) is advised in high-risk patients whose choledocholithiasis has been cleared by ERCP (NIH 1992).

In contrast, retrospective reviews found a higher mortality rate in patients who deferred cholecystectomy after endoscopic sphincterotomy compared to patients who had their gallbladders removed electively (Archibald 2007). Only randomised clinical trials could have determined if prophylactic cholecystectomy reduced 
the risk of death. A recent randomised clinical trial of prophylactic cholecystectomy versus wait-and-see in fit patients found a higher incidence of biliary symptoms in the wait-and-see group, of whom $22(36 \%)$ had cholecystectomy performed in the first 20 months after sphincterotomy (Boerma 2002). No differences were seen in patient survival or in quality of life, but the trial was underpowered for such determinations. An accompanying editorial advised fit patients to undergo prophylactic cholecystectomy following clearance of stones from the bile duct (Cuschieri 2002). This editorial also suggested that the technique for laparoscopic common bile duct exploration had advanced and that it was now the preferred method over ERCP to clear ductal stones because prophylactic cholecystectomy could be performed at the same operation. However, this view is not universally accepted (Barkun 2005).

A systematic review of randomised clinical trials is required to determine the benefits and harms of cholecystectomy deferral after endoscopic sphincterotomy versus prophylactic cholecystectomy after either ERCP or common bile duct exploration.

\section{O B JE C T IVES}

To evaluate the beneficial and harmful effects of cholecystectomy deferral (wait-and-see) versus elective (prophylactic) cholecystectomy in patients who have had an endoscopic biliary sphincterotomy.

\section{METHODS}

\section{Criteria for considering studies for this review}

\section{Types of studies}

Randomised trials were included irrespective of blinding, language, or publication status (ie, unpublished trials, abstracts, or full paper articles).

\section{Types of participants}

Patients with gallbladders left in-situ after endoscopic sphincterotomy.

\section{Types of interventions}

Expectant management (cholecystectomy deferral) versus prophylactic (elective) cholecystectomy. Randomised clinical trials that compared endoscopic sphincterotomy followed by expectant management of the gallbladder with either endoscopic sphincterotomy followed by prophylactic cholecystectomy or with common bile duct exploration and prophylactic cholecystectomy were included. Collateral interventions were permitted if applied equally in both arms of the trial.

\section{Types of outcome measures}

\section{Primary outcome measures}

(1) Mortality.

Secondary outcome measures

(2) Incidence of: biliary pain; recurrent jaundice; pancreatitis; non-biliary abdominal pain; major adverse events; minor adverse events; other morbidities.

(3) Number of patients undergoing subsequent ERCP or percutaneous cholangiogram.

(4) Number of patients undergoing cholecystectomy.

(5) Incidence of 'complicated' cholecystectomy (complicated is defined as the unintended extension of surgery such as conversion of laparoscopic to open cholecystectomy or use of cholecystostomy prior to cholecystectomy).

(6) Quality of life.

(7) Number of patients requiring re-admission to hospital.

(8) Adverse events. They were classified as major if they were considered to threaten life, organ or limb function or to substantially prolong hospital stay. Examples of major adverse events include bile duct transection, myocardial infarction, pulmonary embolism and renal failure. Other adverse events were considered to be minor adverse events. Examples of minor adverse events include cystic duct bile leak, respiratory atelectasis and wound infections ( ICH-GCP 1997).

\section{Search methods for identification of studies}

We performed electronic searches using the search strategies presented in Appendix 1. We manually went through the results obtained through the searches in The Cochrane Hepato-Biliary Group Controlled Trials Register, The Cochrane Controlled Trials Register (CENTRAL) in The Cochrane Library, MEDLINE, EMBASE, and Science Citation Index Expanded. The period of time the separate searches cover is also given in Table 1. Abstracts of Digestive Disease Week were searched for meetings from 1996 to 2006 . We also scanned bibliographies in relevant review articles and wrote to authors of included trials. Two of us (V McAlister, E Davenport) evaluated whether these studies fulfil the inclusion criteria.

\section{Data collection and analysis}

\section{Data extraction}

Two reviewers (V. McAlister and E. Davenport) independently extracted data using standardised extraction forms. Disagreements were resolved by discussion arbitrated by E. Renuof. 
From each trial, we tried to extract the following characteristics:

- Patients (inclusions and exclusion criteria, mean age, sex, indication for endoscopic sphincterotomy);

- Interventions (prophylactic cholecystectomy or expectant management);

- Trials (setting, methodological quality, publication status, duration of follow-up, and all outcomes).

\section{Methodological quality}

Randomisation and follow-up was extracted as measures of methodological quality using the definitions listed below ( Kjaergard 2001).

\section{Generation of the allocation sequence}

To determine if the procedure used to create a random sequence ensured that each patient has a known, unpredictable, and usually equal chance of being assigned to intervention groups, the allocation sequence generation was classified as:

- adequate (if the allocation sequence was generated by a computer or random number table),

- unclear (if the trial was described as randomised, but the method used for the allocation sequence generation was not described), or

- inadequate (if a system involving dates, names, or admittance numbers were used).

\section{Allocation concealment}

The procedure used to conceal the allocation sequence from the investigators who assign patients to the intervention groups was assessed. The allocation concealment was classified as:

- adequate (if the allocation of patients involved a central independent unit, sealed envelopes, on-site locked computer, or identically appearing numbered drug bottles or containers prepared by an independent pharmacist),

- unclear (if the trial was described as randomised, but the method used to conceal the allocation was not described), or

- inadequate (if the trial was quasi-randomised).

\section{Blinding}

Considering the nature of the intervention, we did not expect that any of the eligible trials would be double blind. Double blinding was, therefore, not be included in our assessment of methodological quality. However, we assessed which trials used blinded outcome assessment.

\section{Follow-up}

We extracted the number and reasons for all losses to follow-up to assess the risk of attrition bias.

\section{Statistical analyses}

The analyses was performed in RevMan Analysis 1.0 (RevMan 2003). The number of events and number of patients in all intervention arms was used to calculate relative risks (RR) with 95\% confidence intervals (CI). Data were combined in fixed-effect meta-analyses. Random-effects meta-analyses was performed as sensitivity analyses, but was only reported if the results regarding significance differed from the fixed-effect models. Intentionto-treat analyses including all patients irrespective of compliance or follow-up was performed. Carry forward of the last observed response was used for patients with missing data. For the primary outcome measure, evidence of publication bias and other biases was evaluated in regression analyses of funnel plot asymmetry. Sources of heterogeneity was evaluated through sensitivity, subgroup, and meta-regression analyses. The analyses included the extracted patient, intervention, and trial characteristics listed above as explanatory variables. V. McAlister and E. Renouf entered the data and performed all meta-analyses in RevMan. The impact of open versus laparoscopic cholecystectomy was assessed by sensitivity analysis. Sensitivity analysis was also used to assess the impact of trial design: ERCP alone versus prophylactic cholecystectomy after ERCP or ERCP alone versus prophylactic cholecystectomy after common bile duct exploration.

\section{R E S U L T S}

\section{Description of studies}

See: Characteristics of included studies; Characteristics of excluded studies.

Searches performed on April 18, 2007 resulted in 330 hits which yielded 93 reports when duplicates were removed. After initial review, seven randomised trials were identified of which two were excluded on further examination because the gallbladder was not left in-situ in the patients (Neoptolemos 1987; Kapoor 1996). In three of the included trials a wait-and-see policy for the gallbladder after endoscopic sphincterotomy was compared with open cholecystectomy and removal of the common bile duct stones by exploration (Hammarstrom 1995; Targarona 1996; Suc 1998). In the remaining two trials, a wait-and-see approach regarding the gallbladder after sphincterotomy was compared with prophylactic laparoscopic cholecystectomy after sphincterotomy (Boerma 2002; Lau 2006). The trials, which were conducted in five countries, involved multiple centres in two (Suc 1998; Boerma 2002) and were single-centred in the remaining three (Hammarstrom 1995; Targarona 1996; Lau 2006). The five trials included 662 adult patients of whom 334 were allocated to the wait-and-see group and 328 were allocated to the prophylactic cholecystectomy group. Three trials included patients in all American Society of Anaestesiology (ASA) classes (Hammarstrom 1995; Targarona 1996; Suc 1998) and two trials excluded high risk patients with ASA class IV and V physiological scores (Boerma 2002; Lau 2006).

\section{Risk of bias in included studies}


Allocation concealment was adequate in four trials (Targarona 1996; Suc 1998; Boerma 2002; Lau 2006) but was not described in one (Hammarstrom 1995). None of the trials was blinded. In one trial, eight patients were excluded because they did not have gallbladders-in-situ at the time of randomisation; five in the waitand-see group (Suc 1998) and three were in the surgical group. In two trials, a small number of the patients randomised to the prophylactic cholecystectomy group did not actually have a cholecystectomy (Hammarstrom 1995; Boerma 2002). A follow-up protocol was described in four trials (Hammarstrom 1995; Targarona 1996; Boerma 2002; Lau 2006). The patients were seen in routine clinics and third party observers were not used. The trial duration was disclosed in each trial, but the actual observation period was given in only three (Hammarstrom 1995; Boerma 2002; Lau 2006).

\section{Effects of interventions}

\section{Primary outcome}

All five trials, including 662 patients, reported mortality ( Hammarstrom 1995; Targarona 1996; Suc 1998; Boerma 2002; Lau 2006). Forty seven patients (14.1\%) died in the wait-and-see group and 26 patients $(7.9 \%)$ died in the prophylactic cholecystectomy group (Analysis 1.1: RR 1.78, 95\% CI 1.15 to $2.75, \mathrm{P}=$ $0.010)$. There was no heterogeneity between the trials $\left(i^{2}=0\right)$.

Secondary outcomes
All trials reported all of the secondary outcome measures with the exception of quality-of-life score, which was reported by one trial only (Boerma 2002). Biliary type pain or cholecystitis occurred in $16 \%$ of patients who deferred cholecystectomy and this risk was eliminated by prophylactic cholecystectomy (Analysis 1.2: RR 14.56, 95\% CI 4.95 to $42.78, \mathrm{P}<00001$ ). Only four patients (three in the wait-and-see group and one in the prophylactic cholecystectomy group) developed pancreatitis (Analysis 1.3: RR $2.11,95 \%$ CI 0.39 to $11.43, \mathrm{P}=0.39$ ). Recurrent jaundice or cholangitis was significantly more common in patients who deferred cholecystectomy (Analysis 1.4: RR 2.53, 95\% CI 1.09 to $5.87, \mathrm{P}=0.03$ ). Less adverse events were recorded in patients who deferred cholecystectomy (major adverse events: Analysis 1.5: RR $0.59,95 \%$ CI 0.34 to $1.01, \mathrm{P}=0.06$ and minor adverse events: Analysis 1.6: RR $0.49,95 \%$ CI 0.22 to $0.89, \mathrm{P}=0.03$ ). More patients required subsequent ERCP or other forms of cholangiography if cholecystectomy was deferred (Analysis 1.7: RR 2.36, 95\% CI 1.29 to $4.32, \mathrm{P}=0.005)$. Eight patient randomised to the prophylactic cholecystectomy group did not have a cholecystectomy. Cholecystectomy was eventually performed in 35\% (115 patients) of the wait-and-see group (Table 1). There was no difference in the rate of difficult cholecystectomy between the groups (Analysis 1.8: RR $0.68,95 \%$ CI 0.39 to $1.17, \mathrm{P}=0.16$ ). There were no reports of major or minor bile duct complications following cholecystectomy. Only one trial reported hospital re-admission rates ( Targarona 1996) and only one other collected data regarding the quality of life (Boerma 2002).

Table 1. Actual cholecystectomy rate (prophylactic and therapeutic)

\begin{tabular}{lll}
\hline Trial & Wait-and-see: $\mathbf{n} / \mathbf{N}$ & Prohylactic: $\mathbf{n} / \mathbf{N}$ \\
\hline Hammarstrom 1995 & $14 / 39$ & $41 / 44$ \\
\hline Targarona 1996 & $11 / 50$ & $48 / 48$ \\
\hline Suc 1998 & $56 / 92$ & $102 / 102$ \\
\hline Boerma 2002 & $22 / 59$ & $44 / 49$ \\
\hline Lau 2006 & $12 / 89$ & $82 / 82$ \\
\hline TOTAL & $115 / 329$ & $317 / 325$ \\
\hline
\end{tabular}




\section{Subgroup analyses}

Subgroup analysis was performed according the design of the trials and according to the inclusion of high-risk patients (American Society of Anaesthesiology (ASA) IV or V). A wait-and-see policy for the gallbladder after endoscopic sphincterotomy was compared with open cholecystectomy and removal of the common bile duct stones by exploration in three trials (Hammarstrom 1995; Targarona 1996; Suc 1998) and a wait-and-see approach to the gallbladder after endoscopic sphincterotomy was compared with prophylactic laparoscopic cholecystectomy in the other two (Boerma 2002; Lau 2006) (Analysis 2.1 to Analysis 2.8). Three trials included high-risk patients (ASA IV or V) (Hammarstrom 1995; Targarona 1996; Suc 1998) whereas these patients were excluded in two trials (Boerma 2002; Lau 2006) (Analysis 3.1 to Analysis 3.8). Therefore, subgroup analysis according to each of these stratifications were identical. The combination of different trial design and inclusion of high-risk patients did not alter the primary or secondary outcomes of the meta-analysis.

Similar reductions in mortality rates were seen in each of the subgroups, but combination was required to be statistically significant (Analysis 2.1; Analysis 3.1). Recurrent biliary pain was seen only in the patients who deferred cholecystectomy in all subgroups ( Analysis 2.2; Analysis 3.2). Recurrent jaundice and cholangitis occurred more often in the wait-and-see patients in both subgroups (Analysis 2.4; Analysis 3.4). Additional cholangiography was required more often in the wait-and-see group in trials comparing it to prophylactic cholecystectomy after endoscopic sphincterotomy (Analysis 2.7) and in trials that excluded ASA IV or V patients ( Analysis 3.7), but no difference was present when wait-and-see was compared to open cholecystectomy and common bile duct exploration (Analysis 2.7), or in trials that included high-risk patients (Analysis 3.7). Major adverse events were less common (not statistically significant) in the wait-and-see patients of all subgroups (Analysis 2.5; Analysis 3.5). Minor adverse events were reduced in wait-and-see patients of the trials compared to open cholecystectomy and common bile duct exploration (Analysis 2.6) and in trials that included ASA IV or V patients (Analysis 3.6) but not in trials compared to cholecystectomy after sphincterotomy (Analysis 2.6) nor in trials that excluded high risk patients. The eventual cholecystectomy rate was $44.8 \%$ (81 patients) and 23\% (34 patients) in the wait-and-see group from the open surgery era and the laparoscopic surgery era respectively (Table 1), but no difference in the incidence of difficult cholecystectomy was seen between the eventual and prophylactic cholecystectomies in either era (Analysis 2.8) nor between trials that included or excluded high risk patients (Analysis 3.8).

\section{Sensitivity analyses}

The influence of each trial on outcome was tested by excluding each trial in rotation and performing pooled analyses of the remaining four trials. The benefit of prophylactic cholecystectomy remained substantial despite removal of each of the trials, one at a time, from the analysis. The relative risk of death is given after the title of each trial which was excluded in the following sensitivity analyses: Boerma 2002 (RR 1.84, 95\% CI 1.17 to 2.83); Hammarstrom 1995 (RR 1.48, 95\% CI 0.89 to 2.44); Lau 2006 (RR 1.92, 95\% CI 1.09 to 3.4); Suc 1998 (RR 1.72, 95\% CI 1.1 to 2.69 ); Targarona 1996 (RR 2.04, 95\% CI 1.22 to 3.41 ). The relative risk of biliary pain is given after the title of each trial which was excluded in the following sensitivity analyses: Boerma 2002 (RR 9.49, 95\% CI 2.96 to 30.38); Hammarstrom 1995 (RR 12.83, 95\% CI 3.96 to 41.60); Lau 2006 (RR 17.92, 95\% CI 5.11 to 64.07); Suc 1998 (RR 15.26, 95\% 4.79 to 48.68); Targarona 1996 (RR 18.49, 95\% CI 5.19 to 65.86). The relative risk of jaundice or cholangitis is given after the title of each trial which was excluded in the following sensitivity analyses: Boerma 2002 (RR 2.54, 1.06 to 6.07); Hammarstrom 1995 (RR 2.53, 95\% CI 1.09 to 5.87); Lau 2006 (RR 2.89, 95\% CI 0.58 to 14.37); Suc 1998 (RR 2.76, 95\% CI 1.13 to 6.72); Targarona 1996 (RR 2.22, 95\% CI 0.91 to 5.37 ). Exclusion of any one trial did not qualitatively alter RR but the $95 \%$ CI for some of the analyses crossed unity if the following studies were excluded: Hammarstrom 1995 (RR mortality 1.48 , 95\% CI 0.89 to 2.44 ); Lau 2006 (RR recurrent jaundice or cholangitis $2.89,95 \%$ CI 0.58 to 14.37 ) and Targarona 1996 (RR recurrent jaundice or cholangitis 2.22, 95\% CI 0.91 to 5.37 ).

\section{I S C U S S I O N}

The main conclusions of our review are that the wait-and-see procedure versus removal of the gallbladder leads to more deaths, more patients with biliary pain and cholangitis, more patients with recurrent jaundice and cholangitis, and more additional cholangiographies, but saves cholecystectomies and adverse events. The major limitations of our review are the relatively few trials, the few patients, and the low number of outcomes as well as methodological weaknesses of the trials.

One of the included trials demonstrated a statistically significant increase in mortality in patients deferring cholecystectomy after endoscopic sphincterotomy and clearance of the bile duct ( Hammarstrom 1995). This trial had a small sample size and its finding might be considered a matter of chance. Subsequent studies were not sufficiently powered to show differences in survival and therefore could not confirm the finding. A surprisingly large proportion of patients have been reported to adopt a wait-and-see policy after sphincterotomy, indicating that neither physicians nor patients have been convinced by the trials individually (Archibald 2007). This meta-analysis confirms the finding that prophylactic cholecystectomy after endoscopic sphincterotomy reduces mortality. This reduction in mortality was seen particularly in trials that included all patients, even those in the higher risk ASA classes. This finding was evident even though most of the high-risk pa- 
tients were in trials that compared a wait-and-see policy to open surgery. Cholecystectomy deferral has been advised for high risk patients, but this meta-analysis suggests that the benefit of prophylactic cholecystectomy may accrue particularly to that group of patients.

Technological developments have defined eras in the management of cholelithiasis. The development of ERCP in the late 1980s and of laparoscopy in the 1990s changed the management of gallbladder and common bile duct stones. Randomised clinical trials of a wait-and-see policy were designed to use as a control the technology of their era for bile duct clearance and cholecystectomy. Subgroup analysis showed the superiority of prophylactic cholecystectomy to occur regardless of study design. Superiority of prophylactic cholecystectomy was present even in patients who had open surgery. The laparoscopic approach reduces the morbidity of cholecystectomy and has extended use of the procedure into groups of patients previously thought too frail for open surgery ( Barkun 2005). It is reasonable to consider prophylactic cholecystectomy for patients in all risk categories after endoscopic sphincterotomy. However, no trial of prophylactic cholecystectomy has yet been carried out in patients initially considered high-risk for surgery.

Laparoscopic common bile duct exploration may alter the options available to deal with choledocholithiasis once again (Cuschieri 2002). Avoiding the risk of pancreatitis that is inherent with endoscopic sphincterotomy is an attractive element of common bile duct exploration. Of the patients who underwent common bile duct clearance followed by prophylactic cholecystectomy in this review, $7.1 \%$ died in the earlier era where choledocholithiasis was dealt with by open common bile duct exploration, whereas $9.2 \%$ died in the later endoscopic / laparoscopic era. More trials will be required as new technological solutions, such as robot-assisted common bile duct exploration with its capacity for articulated dissection, are deployed. This meta-analysis demonstrates the importance of designing such trials with appropriate power.

\section{A U THORS' CONCLUSIONS Implications for practice}

Prophylactic cholecystectomy should be offered to all patients considered fit for surgery, in whom choledocholithiasis has been cleared by ERCP and endoscopic sphincterotomy.

\section{Implications for research}

Prophylactic cholecystectomy following clearance of choledocholithiasis should be studied by randomised clinical trial in patients considered high-risk for surgery.

Future trials should be reported following the recommendations of the CONSORT statement (www.consort-statement.org).

\section{ACKNOWLEDGEMENTS}

We are grateful to Sarah Louise Klingenberg, Trials Search Coordinator of the Cochrane Hepato-Biliary Group, for assistance with searches undertaken for this study. We are also grateful to the editors and reviewers for their patient advice which improved this report.

Peer reviewers: SC Schmidt, Germany; JC Berthou, France.

Contact Editor: A Fingerhut, France.

\section{REFERENCES}

\section{References to studies included in this review}

Boerma 2002 \{published data only\}

Boerma D, Rauws EA, Keulemans YC, Janssen IM, Bolwerk CJ, Timmer R, et al.Wait-and-see policy or laparoscopic cholecystectomy after endoscopic sphincterotomy for bile-duct stones: a randomised trial. Lancet 2002;360:761-5. [MEDLINE: 12241833]

Hammarstrom 1995 \{published data only\}

Hammarstrom LE, Holmin T, Stridbeck H, Ihse I. Long-term follow-up of a prospective randomized study of endoscopic versus surgical treatment of bile duct calculi in patients with gallbladder in situ. BMJ (Clinical Research Ed.) 1995;82(11):1516-21. [MEDLINE: 8535807]

Lau 2006 \{published data only\} Lau JY, Leow CK, Fung TM, Suen BY, Yu LM, Lai PB, et al.Cholecystectomy or gallbladder in situ after endoscopic sphincterotomy and bile duct stone removal in Chinese patients. Gastroenterology 2006;130(1):96-103. [MEDLINE: 16401473]

Suc 1998 \{published data only\}

Suc B, Escat J, Cherqui D, Fourtanier G, Hay JM, Fingerhut A, Millat B. Surgery vs endoscopy as primary treatment in symptomatic patients with suspected common bile duct stones. A multicenter randomized trial. Archives of Surgery 1998;133(7): $702-08$.

Targarona 1996 \{published data only\}

Targarona EM, Ayuso RM, Bordas JM, Ros E, Pros I, Martinez J, et al.Randomised trial of endoscopic sphincterotomy with gallbladder left in situ versus open surgery for common bileduct calculi in highrisk patients. Lancet 1996;347(9006):926-9. [: 8598755]

References to studies excluded from this review 


\section{Kapoor 1996 \{published data only\}}

Kapoor R, Kaushik S-P, Saraswat V-A, Choudhuri G, Sikora S-S, Saxena R, et al.Prospective randomized trial comparing endoscopic sphincterotomy followed by surgery with surgery alone in good risk patients with choledocholithiasis. Hepatobiliary and Pancreatic Surgery 1996;9(3):145-8. [MEDLINE: 8725454]

Neoptolemos 1987 \{published data only\}

Neoptolemos JP, Carr Locke DL, Fossard DP. Prospective randomised study of preoperative endoscopic sphincterotomy versus surgery alone for common bile duct stones. British Medical Journal (Clinical Research Ed.) 1987;294(6570):470-4.

[MEDLINE: 3103731$]$

\section{Additional references}

\section{Archibald 2007}

Archibald JD, Love JR, McAlister VC. The role of prophylactic cholecystectomy versus deferral in the care of patients after endoscopic sphincterotomy. Canadian Journal of Surgery 2007;50 (1):19-23. [MEDLINE: 17391611]

Barkun 2005

Barkun J, Dixon E, Strasberg S, Evidence Based Reviews in Surgery Group. Canadian Association of General Surgeons and American College of Surgeons evidence based reviews in surgery. 13. Waitand-see policy or laparoscopic cholecystectomy after endoscopic sphincterotomy for bile-duct stones. Canadian Journal of Surgery 2005;48(3):244-6. [MEDLINE: 16013632]

\section{Cuschieri 2002}

Cuschieri A. Management of patients with gallstones and ductal calculi. Lancet 2002;360:739-40. [MEDLINE: 12241828]

\section{Escourrou 1984}

Escourrou J, Cordova JA, Lazorthes F, Frexinos J, Ribet A. Early and late complications after endoscopic sphincterotomy for biliary lithiasis with and without the gallbladder 'in situ'. Gut 1984;25: 598-602. [MEDLINE: 6735245]

\section{ICH-GCP 1997}

International Conference on Harmonisation Expert Working Group. Code of Federal Regulations \& International Conference on Harmonization Guidelines. Media: Parexel Barnett, 1997.

\section{Kjaergard 2001}

Kjaergard LL, Villumsen J, Gluud C. Reported methodologic quality and discrepancies between large and small randomized trials in meta-analyses. Annals of Internal Medicine 2001;135(11):982-9. [MEDLINE: 11730399]

\section{NIH 1992}

NIH Consensus Development Conference Statement. Gallstones and laparoscopic cholecystectomy. www.consensus.nih.gov/1992/ 1992GallstonesLaparoscopy090html.htm (accessed 23 August 2006).

\section{NIH 2002}

National Institutes of Health State-of-the-Science Conference Statement. Endoscopic retrograde cholangiopancreatography (ERCP) for diagnosis and therapy. http://consensus.nih.gov/2002/ 2002ERCPsos020html.htm (accessed 23 August 2006).

\section{RevMan 2003}

Copenhagen: The Nordic Cochrane Centre, The Cochrane Collaboration. Review Manager (RevMan). 4.2 for Windows. Copenhagen: The Nordic Cochrane Centre, The Cochrane Collaboration, 2003.

\section{Roy 1993}

Roy A, McAlister V, Passi RB. Endoscopic retrograde cholangiopancreatography in the management of choledocholithiasis with laparoscopic cholecystectomy. Canandian Journal of Surgery 1993;36:81-4. [MEDLINE: 8443724]

* Indicates the major publication for the study 


\section{CHARACTERISTICS OF STUDIES}

\section{Characteristics of included studies [ordered by study ID]}

Boerma 2002

\begin{tabular}{|c|c|c|}
\hline Methods & \multicolumn{2}{|c|}{$\begin{array}{l}\text { Generation of the allocation sequence: adequate. Computer randomisation with stratification according } \\
\text { to participating hospital and whether older or younger than } 65 \text { years. } \\
\text { Allocation concealment: adequate. Central allocation. } \\
\text { Blinding: not performed. } \\
\text { Follow-up: } 5 / 64 \text { in the wait-and-see group and } 7 / 56 \text { in the prophylactic cholecystectomy group were } \\
\text { immediately lost to follow-up. } \\
\text { Analysis: intention to treat excluding those immediately lost to follow-up. }\end{array}$} \\
\hline Participants & \multicolumn{2}{|c|}{$\begin{array}{l}\text { Country and setting: Netherlands, one Academic Heath Centre and eight Community Hospitals. } \\
\text { Language: English. } \\
\text { Inclusion criteria: consecutive male and female patients, aged } 18 \text { to } 80 \text { having ERCP/ES with successful } \\
\text { extraction of CBD stones and radiographically-proven choledocholithiasis. } \\
\text { Exclusion criteria: ASA IV or V, deemed unfit for surgery. } \\
\text { Allocation: ES with wait-and-see }=49 \text {; prophylactic cholecystectomy }=59 \text {. }\end{array}$} \\
\hline Interventions & \multicolumn{2}{|c|}{$\begin{array}{l}\text { Wait-and-see group: ES with “on-demand" cholecystectomy. } \\
\text { Prophylactic cholecystectomy group: laparoscopic cholecystectomy within } 6 \text { weeks of ES. }\end{array}$} \\
\hline Outcomes & \multicolumn{2}{|c|}{$\begin{array}{l}\text { Primary outcome: recurrence of at least } 1 \text { biliary event during } 2 \text { year follow-up (biliary pain, acute } \\
\text { cholecystitis, cholangitis, pancreatitis, obstructive jaundice, gallstone ileus, GB carcinoma). } \\
\text { Secondary outcome: complications of cholecystectomy, quality-of-life (measured using MOS-24). } \\
\text { Complications: post-procedure complications. }\end{array}$} \\
\hline Notes & \multicolumn{2}{|c|}{$\begin{array}{l}\text { Follow-up: median follow up: } 30 \text { months. } \\
\text { 'Other' outcomes and/or adverse events of interest: mortality, additional ERCP, conversion to open chole- } \\
\text { cystectomy. }\end{array}$} \\
\hline \multicolumn{3}{|l|}{ Risk of bias } \\
\hline Item & Authors' judgement & Description \\
\hline Allocation concealment? & Yes & A - Adequate \\
\hline
\end{tabular}

Hammarstrom 1995

Gethods
Allocation concealment: unclear.
Blinding: not performed.
Follow-up: three of 44 patients in the prophylactic cholecystectomy group and none of 39 in the wait-
and-see group were lost to follow-up.
Analysis: intention to treat.




\begin{tabular}{l} 
Country and setting: Sweden, academic health centre. \\
Language: English. \\
Inclusion criteria: male and female patients, aged 55 to 85 with demonstration of CBD stones (by ERCP \\
in 79 patients, ultrasonography in 2 patients, or infusion cholangiography in 2 patients). \\
Exclusion criteria: previous cholecystectomy, unfit for surgery, concomitant malignancy, Billroth II gas- \\
trectomy, refused participation, perforated cholecystitis, referred from local hospital. \\
Allocation: wait-and-see $=39$, prophylactic cholecystectomy $\mathrm{n}=44$. \\
\hline
\end{tabular}

Interventions $\quad$ Wait-and-see group: ERCP and ES with eventual cholecystectomy if required. (Authors do not state if the laparoscopic or open approach is to be taken).

Prophylactic cholecystectomy group: open cholecystectomy with supraduodenal bile duct exploration and T-tube placement in all patients; 25 of 41 patients had choledochoscopy.

\begin{tabular}{ll} 
Outcomes & $\begin{array}{l}\text { Authors do not explicitly state which of their outcomes were considered to be primary and which are } \\
\text { secondary. } \\
\text { Outcome was assessed in terms of mortality, major (life-threatening)and minor (non-life threatening) } \\
\text { complications, length of hospital stay, and late morbidity. }\end{array}$ \\
\hline Notes & $\begin{array}{l}\text { Follow-up: for wait-and see group median follow-up was } 92 \text { months and for cholecystectomy group } \\
\text { median follow-up was } 82 \text { months. } \\
\text { Total median hospital stay of } 13 \text { days was reported only for the ES group (no hospital length of stay data } \\
\text { for the surgical group) } \\
\text { Other outcomes of interest: repeat ERCP. }\end{array}$
\end{tabular}

Risk of bias

\begin{tabular}{lll}
\hline Item & Authors' judgement & Description \\
\hline Allocation concealment? & Unclear & B - Unclear \\
\hline
\end{tabular}

Lau 2006

\begin{tabular}{|c|c|}
\hline Methods & $\begin{array}{l}\text { Generation of the allocation sequence: adequate. Randomly assigned using computer-generated random } \\
\text { list. } \\
\text { Allocation concealment: adequate. Performed by research nurse from computer. } \\
\text { Blinding: not performed. } \\
\text { Follow-up: no patients lost to follow-up. }\end{array}$ \\
\hline Participants & $\begin{array}{l}\text { Country and setting: Hong Kong, Academic Health Centre. } \\
\text { Language: English. } \\
\text { Inclusion criteria: consecutive patients who underwent complete sphincterotomy and complete removal of } \\
\text { CBD stones eligible if radiologic evidence of intact GB containing stones and no previous hospitalisation } \\
\text { for cholecystitis. } \\
\text { Exclusion criteria: age }>90 \text {, evidence of concomitant intrahepatic ductal stones, radiologic evidence of } \\
\text { recurrent pyogenic cholangitis, no consent to trial entry, intercurrent malignancy with limited life span, } \\
\text { unfit for cholecystectomy (ASA class IV or V). } \\
\text { Allocation: wait-and-see }=88 \text {, prophylactic cholecystectomy } n=82 \text {. }\end{array}$ \\
\hline
\end{tabular}




\begin{tabular}{|c|c|c|}
\hline Interventions & \multicolumn{2}{|c|}{$\begin{array}{l}\text { Wait-and-see group: ES with possible eventual cholecystectomy. } \\
\text { Prophylactic cholecystectomy group: laparoscopic cholecystectomy after ES. }\end{array}$} \\
\hline Outcomes & \multicolumn{2}{|c|}{$\begin{array}{l}\text { Primary outcome: further biliary complications presenting with cholangitis, pancreatitis, jaundice, com- } \\
\text { plicated gallstones presenting with biliary colic (as defined by the Rome II criteria), or cholecystitis . } \\
\text { Secondary outcome: adverse events, late deaths from all causes, outcomes after cholecystectomy. }\end{array}$} \\
\hline Notes & \multicolumn{2}{|c|}{$\begin{array}{l}\text { Follow-up: mean follow-up in the prophylactic cholecystectomy group was } 65.5 \text { months, compared with } \\
58.5 \text { months in the wait-and-see group. } \\
\text { 'Other' outcomes and/or adverse events of interest included mortality, additional ERCP, conversion to } \\
\text { open surgery, median hospital stay during index admission. }\end{array}$} \\
\hline \multicolumn{3}{|l|}{ Risk of bias } \\
\hline Item & Authors' judgement & Description \\
\hline Allocation concealment? & Yes & A - Adequate \\
\hline
\end{tabular}

\section{Suc 1998}

Gethods
Allocation of concealment: adequate. Central allocation.
Blinding: not performed.
Follow-up: not described.

Country and setting: France, nine university hospitals, eight teaching hospitals and one private hospital.
Language: English.
Inclusion criteria: consecutive patients with one or more of: clinical symptoms including jaundice, mild
acute pancreatitis with Ranson score less than or equal to 2, mild acute cholangitis, biliary colic with
increased alkaline phophatase levels, CBD stones, or CBD diameter $>1 \mathrm{~cm}$ on ultrasonography.
Exclusion criteria: cholecystitis (GB wall $>3 \mathrm{~mm}$ on US), no cholelithiasis visible on US, CBD diameter
$<1 \mathrm{~cm}$, previous total gastrectomy, B2, or choledochoenterostomy.
Allocation: wait-and-see - 95 ( 5 already had GB removed at time of randomisation); prophylactic chole-
cystectomy group - 105 (3 already GB removed at time of randomisation).

Interventions

Wait-and-see group: ERCP followed by cholecystectomy if required later.

Prophylactic cholecystectomy group: open cholecystectomy and open CBD exploration.

Outcomes Primary outcome: number of patients requiring an additional procedure.

Secondary outcomes: mortality, major complications, duration of hospital stay.

Notes

Risk of bias

Item

Authors' judgement

\section{Description}




\section{Suc 1998 (Continued)}

Allocation concealment? Yes $\quad$ A - Adequate

\section{Targarona 1996}

Methods

Generation of the allocation sequence: adequate. Patients randomly assigned to one of two arms and stratified according to presence of jaundice or pancreatitis.

Allocation concealment: adequate. Sequentially numbered, sealed envelopes.

Blinding: not performed.

Follow-up: adequate. Follow-up: 3/48 of prophylactic cholecystectomy group and 1/50 of wait-and-see group lost to follow-up.

Analysis: intention to treat.

\begin{tabular}{|c|c|}
\hline Participants & $\begin{array}{l}\text { Country and setting: Spain, on academic health centre. } \\
\text { Language: English. } \\
\text { Inclusion criteria: all male and female 'high-risk' gallstone patients (at least one of: age over } 70 \text {; Goldman } \\
\text { cardiac risk index }>13 \text {; chronic pulmonary disease with a predicted postoperative maximum sustained } \\
\text { ventilation }<10 \mathrm{~L} / \mathrm{min} \text {; liver cirrhosis type B or C of the Child-Pugh classification; neurologic deficit } \\
\text { or joint disease associated with severely impaired mobility; BMI }>30 \text { ) presenting with biliary pain and } \\
\text { jaundice, pancreatitis, cholangitis, or any combination thereof, and suspected of having common bile } \\
\text { duct stones were candidates for inclusion. } \\
\text { Diagnostic criteria used for bile duct stones: cholestasis associated with evidence of GB stones and CBD } \\
>8 \mathrm{~mm} \text { and/or duct stones by abdominal US or ERCP. If ERCP required for diagnosis then patient } \\
\text { randomised during the procedure. } \\
\text { Exclusion criteria: patient refusal, previous surgical or endoscopic interventions on the biliary tree, pre- } \\
\text { senting with severe cholangitis or biliary pancreatitis requiring urgent ES. } \\
\text { Allocation: ES with GB in situ }=50 \text {; cholecystectomy }=48 \text {. }\end{array}$ \\
\hline
\end{tabular}

Interventions $\quad$ Wait-and-see group: ES with cholecystectomy later if required.

Prophylactic cholecystectomy group: open cholecystectomy with CBD exploration if indicated by intraoperative cholangiography.

Outcomes

Authors do not explicitly state which of their outcomes are primary and which are secondary.

Outcomes assessed:

(1) immediate, procedure-related: mortality and morbidity, severe complications, minor complications, pre-procedure and post-procedure hospital length of stay.

(2) during long-term follow-up: biliary complications, readmission for biliary complications, cholecystectomy, ERCP, late morbidity.

Notes

Early follow-up defined as follow-up to hospital discharge. Late follow-up protocol included a visit at 30 days or so after discharge and then every three months for first year and every six months thereafter for the length of the study.

\section{Risk of bias}

\begin{tabular}{l|ll}
\hline Item & Authors' judgement & Description \\
\hline Allocation concealment? & Yes & A - Adequate \\
\hline
\end{tabular}




\section{Abbreviations}

ASA: American Society of Anesthesiology physiological status score

CBD: Common bile duct

GB: Gallbladder

ERCP: Endoscopic Retrograde Cholangiopancreatography

ES: Endoscopic sphincterotomy

Characteristics of excluded studies [ordered by study ID]

Kapoor 1996 A randomised clinical trial. Neither treatment arm included patients left with gallbladder in situ.

Neoptolemos 1987 A randomised clinical trial. Neither treatment arm included patients left with gallbladder in situ. 
DATA AND ANALYSES

Comparison 1. Wait-and-see versus prophylactic cholecystectomy

\begin{tabular}{lccll} 
Outcome or subgroup title & $\begin{array}{c}\text { No. of } \\
\text { studies }\end{array}$ & $\begin{array}{c}\text { No. of } \\
\text { participants }\end{array}$ & Statistical method & Effect size \\
\hline 1 Mortality & 5 & 662 & Risk Ratio (M-H, Fixed, 95\% CI) & $1.78[1.15,2.75]$ \\
2 Biliary pain or cholecystitis & 5 & 654 & Risk Ratio (M-H, Fixed, 95\% CI) & $14.56[4.95,42.78]$ \\
3 Pancreatitis & 5 & 662 & Risk Ratio (M-H, Fixed, 95\% CI) & $2.11[0.39,11.43]$ \\
4 Recurrent jaundice or cholangitis & 5 & 662 & Risk Ratio (M-H, Fixed, 95\% CI) & $2.53[1.09,5.87]$ \\
5 Major adverse events & 5 & 662 & Risk Ratio (M-H, Fixed, 95\% CI) & $0.60[0.35,1.02]$ \\
6 Minor adverse events & 5 & 662 & Risk Ratio (M-H, Fixed, 95\% CI) & $0.45[0.22,0.91]$ \\
7 Additional cholangiography & 5 & 662 & Risk Ratio (M-H, Fixed, 95\% CI) & $2.36[1.29,4.32]$ \\
$\quad$ (ERCP or PTC) & 5 & 654 & Risk Ratio (M-H, Fixed, 95\% CI) & $0.68[0.39,1.17]$ \\
8 Difficult cholecystectomy & 5 & &
\end{tabular}

Comparison 2. Stratified by method of cholecystectomy

\begin{tabular}{|c|c|c|c|c|}
\hline Outcome or subgroup title & $\begin{array}{l}\text { No. of } \\
\text { studies }\end{array}$ & $\begin{array}{c}\text { No. of } \\
\text { participants }\end{array}$ & Statistical method & Effect size \\
\hline 1 Mortality & 5 & 662 & Risk Ratio (M-H, Fixed, 95\% CI) & $1.70[1.10,2.64]$ \\
\hline $\begin{array}{l}1.1 \text { Open cholecystectomy \& } \\
\text { common bile duct exploration }\end{array}$ & 3 & 383 & Risk Ratio (M-H, Fixed, 95\% CI) & $1.86[1.03,3.35]$ \\
\hline $\begin{array}{l}1.2 \text { Laparoscopic } \\
\text { cholecystectomy after } \\
\text { sphincterotomy }\end{array}$ & 2 & 279 & Risk Ratio (M-H, Fixed, 95\% CI) & $1.53[0.79,2.94]$ \\
\hline 2 Biliary pain or cholecystitis & 5 & 654 & Risk Ratio (M-H, Fixed, 95\% CI) & $14.56[4.95,42.78]$ \\
\hline $\begin{array}{l}2.1 \text { Open cholecystectomy } \& \\
\text { common bile duct exploration }\end{array}$ & 3 & 375 & Risk Ratio (M-H, Fixed, 95\% CI) & $11.09[2.69,45.79]$ \\
\hline $\begin{array}{l}2.2 \text { Laparoscopic } \\
\text { cholecystectomy after } \\
\text { spincterotomy }\end{array}$ & 2 & 279 & Risk Ratio (M-H, Fixed, 95\% CI) & $18.84[3.66,97.00]$ \\
\hline 3 Pancreatitis & 5 & 662 & Risk Ratio (M-H, Fixed, 95\% CI) & $2.11[0.39,11.43]$ \\
\hline $\begin{array}{l}3.1 \text { Open cholecystectomy } \& \\
\text { common bile duct exploration }\end{array}$ & 3 & 383 & Risk Ratio (M-H, Fixed, 95\% CI) & $2.11[0.39,11.43]$ \\
\hline $\begin{array}{l}\text { 3.2 Laparoscopic } \\
\text { cholecystectomy after } \\
\text { sphincterotomy }\end{array}$ & 2 & 279 & Risk Ratio (M-H, Fixed, 95\% CI) & Not estimable \\
\hline 4 Recurrent jaundice or cholangitis & 5 & 662 & Risk Ratio (M-H, Fixed, 95\% CI) & $2.53[1.09,5.87]$ \\
\hline $\begin{array}{l}4.1 \text { Open cholecystectomy \& } \\
\text { common bile duct exploration }\end{array}$ & 3 & 383 & Risk Ratio (M-H, Fixed, 95\% CI) & $3.04[0.47,19.49]$ \\
\hline $\begin{array}{l}\text { 4.2 Laparoscopic } \\
\text { cholecystectomy after } \\
\text { sphincterotomy }\end{array}$ & 2 & 279 & Risk Ratio (M-H, Fixed, 95\% CI) & $2.41[0.94,6.18]$ \\
\hline 5 Major adverse events & 5 & 662 & Risk Ratio (M-H, Fixed, 95\% CI) & $0.60[0.35,1.02]$ \\
\hline
\end{tabular}


5.1 Open cholecystectomy \& common bile duct exploration

5.2 Laparoscopic

cholecystectomy after

sphincterotomy

6 Minor adverse events

6.1 Open cholecystectomy \& common bile duct exploration

6.2 Laparoscopic

cholecystectomy after

sphincterotomy

7 Additional cholangiography

(ERCP or PTC)

7.1 Open cholecystectomy \& common bile duct exploration

7.2 Laparoscopic

cholecystectomy after

sphincterotomy

8 Difficult cholecystectomy

8.1 Open cholecystectomy \&

common bile duct exploration

8.2 Laparoscopic

cholecystectomy after

sphincterotomy

\section{Comparison 3. Stratified by patient ASA class}

\begin{tabular}{|c|c|c|c|c|}
\hline Outcome or subgroup title & $\begin{array}{l}\text { No. of } \\
\text { studies }\end{array}$ & $\begin{array}{c}\text { No. of } \\
\text { participants }\end{array}$ & Statistical method & Effect size \\
\hline 1 Mortality & 5 & 662 & Risk Ratio (M-H, Fixed, 95\% CI) & $1.70[1.10,2.64]$ \\
\hline $\begin{array}{l}\text { 1.1 Studies with inclusion of } \\
\text { high-risk patients (ASA IV or } \\
\text { V) }\end{array}$ & 3 & 383 & Risk Ratio (M-H, Fixed, 95\% CI) & $1.86[1.03,3.35]$ \\
\hline $\begin{array}{l}1.2 \text { Studies with exclusion of } \\
\text { high-risk patients (ASA IV or } \\
\text { V) }\end{array}$ & 2 & 279 & Risk Ratio (M-H, Fixed, 95\% CI) & $1.53[0.79,2.94]$ \\
\hline 2 Biliary pain or cholecystitis & 5 & 654 & Risk Ratio (M-H, Fixed, 95\% CI) & $14.56[4.95,42.78]$ \\
\hline $\begin{array}{l}2.1 \text { Studies with inclusion of } \\
\text { high-risk patients (ASA IV or } \\
\text { V) }\end{array}$ & 3 & 375 & Risk Ratio (M-H, Fixed, 95\% CI) & $11.09[2.69,45.79]$ \\
\hline $\begin{array}{l}2.2 \text { Studies with exclusion of } \\
\text { high-risk patients (ASA IV or } \\
\text { V) }\end{array}$ & 2 & 279 & Risk Ratio (M-H, Fixed, 95\% CI) & $18.84[3.66,97.00]$ \\
\hline 3 Pancreatitis & 5 & 662 & Risk Ratio (M-H, Fixed, 95\% CI) & $2.11[0.39,11.43]$ \\
\hline $\begin{array}{l}\text { 3.1 Studies with inclusion of } \\
\text { high-risk patients (ASA IV or } \\
\text { V) }\end{array}$ & 3 & 383 & Risk Ratio (M-H, Fixed, 95\% CI) & $2.11[0.39,11.43]$ \\
\hline
\end{tabular}


3.2 Studies with exclusion of high-risk patients (ASA IV or V)

4 Recurrent jaundice or cholangitis 4.1 Studies with inclusion of high-risk patients (ASA IV or V)

4.2 Studies with exclusion of high-risk patients (ASA IV or V)

5 Major adverse events

5.1 Studies with inclusion of high-risk patients (ASA IV or V)

5.2 Studies with exclusion of high-risk patients (ASA IV or V)

6 Minor adverse events

6.1 Studies with inclusion of high-risk patients (ASA IV or $\mathrm{V})$

6.2 Studies with exclusion of high-risk patients (ASA IV or V)

7 Additional cholangiography (ERCP or PTC)

7.1 Studies with inclusion of high-risk patients (ASA IV or V)

7.2 Studies with exclusion of high-risk patients (ASA IV or V)

8 Difficult cholecystectomy 8.1 Studies with inclusion of high-risk patients (ASA IV or V)

8.2 Studies with exclusion of high-risk patients (ASA IV or V) 


\section{Analysis I.I. Comparison I Wait-and-see versus prophylactic cholecystectomy, Outcome I Mortality.}

\begin{tabular}{|c|c|c|c|c|c|}
\hline \multicolumn{6}{|c|}{ Comparison: I Wait-and-see versus prophylactic cholecystectomy } \\
\hline Outcome: I Mortality & & & & & \\
\hline \multirow[t]{2}{*}{ Study or subgroup } & \multirow{2}{*}{$\begin{array}{r}\text { Wait-and-see } \\
\mathrm{n} / \mathrm{N}\end{array}$} & Prophylactic removal & \multirow{2}{*}{$\begin{array}{c}\text { Risk Ratio } \\
\text { M-H,Fixed,95\% Cl }\end{array}$} & \multirow[t]{2}{*}{ Weight } & \multirow{2}{*}{$\begin{array}{r}\text { Risk Ratio } \\
\text { M-H,Fixed,95\% Cl }\end{array}$} \\
\hline & & $\mathrm{n} / \mathrm{N}$ & & & \\
\hline Boerma 2002 & 1/59 & $1 / 49$ & + & $4.1 \%$ & $0.83[0.05,12.94]$ \\
\hline Hammarstrom 1995 & $14 / 39$ & $5 / 44$ & $\rightarrow$ & $17.8 \%$ & $3.16[1.25,7.97]$ \\
\hline Lau 2006 & $19 / 89$ & $11 / 82$ & 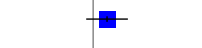 & $43.4 \%$ & $1.59[0.81,3.14]$ \\
\hline Suc 1998 & $3 / 97$ & $1 / 105$ & -1 & $3.6 \%$ & $3.25[0.34,30.70]$ \\
\hline Targarona 1996 & $10 / 50$ & $8 / 48$ & - & $31.0 \%$ & $1.20[0.52,2.78]$ \\
\hline Total $(95 \% \mathrm{CI})$ & 334 & 328 & $\hookrightarrow$ & $100.0 \%$ & $1.78[1.15,2.75]$ \\
\hline \multicolumn{6}{|c|}{ Total events: 47 (Wait-and-see), 26 (Prophylactic removal) } \\
\hline \multicolumn{6}{|c|}{ Heterogeneity: $\mathrm{Chi}^{2}=2.99, \mathrm{df}=4(\mathrm{P}=0.56) ; \mathrm{I}^{2}=0.0 \%$} \\
\hline \multicolumn{6}{|c|}{ Test for overall effect: $Z=2.59(P=0.0097)$} \\
\hline
\end{tabular}

Analysis I.2. Comparison I Wait-and-see versus prophylactic cholecystectomy, Outcome 2 Biliary pain or cholecystitis.

Review: Cholecystectomy deferral in patients with endoscopic sphincterotomy

Comparison: I Wait-and-see versus prophylactic cholecystectomy

Outcome: 2 Biliary pain or cholecystitis

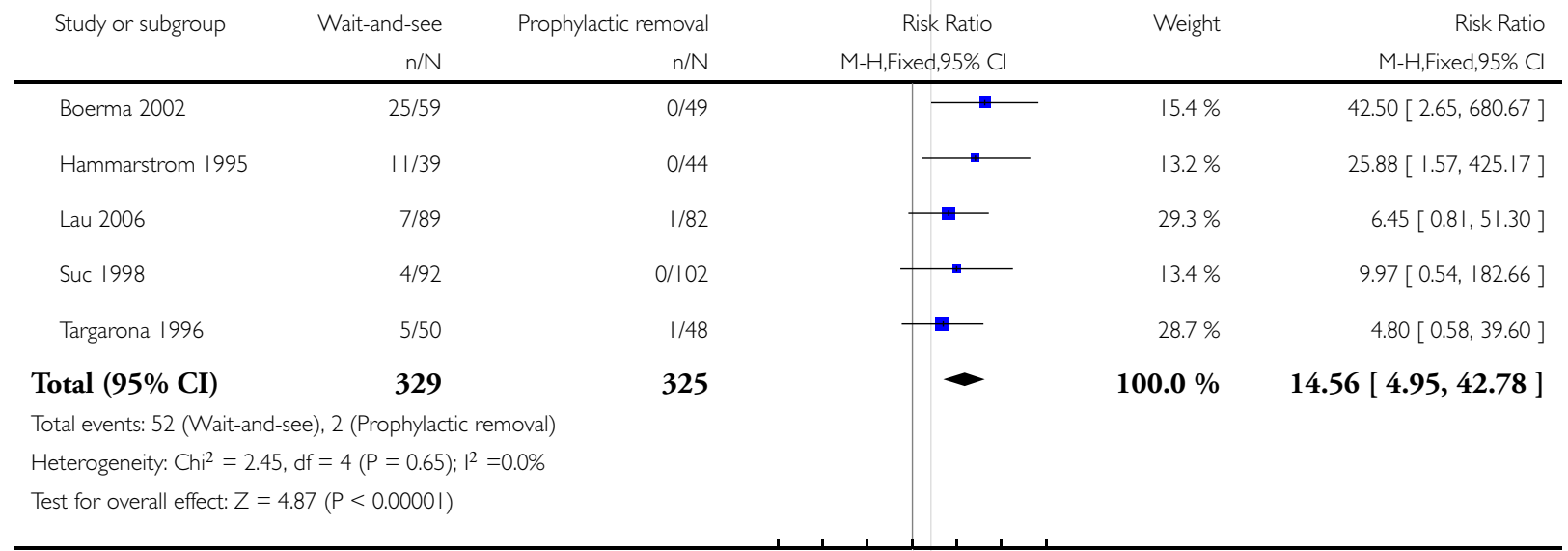




\section{Analysis I.3. Comparison I Wait-and-see versus prophylactic cholecystectomy, Outcome 3 Pancreatitis.}

Review: Cholecystectomy deferral in patients with endoscopic sphincterotomy

Comparison: I Wait-and-see versus prophylactic cholecystectomy

Outcome: 3 Pancreatitis

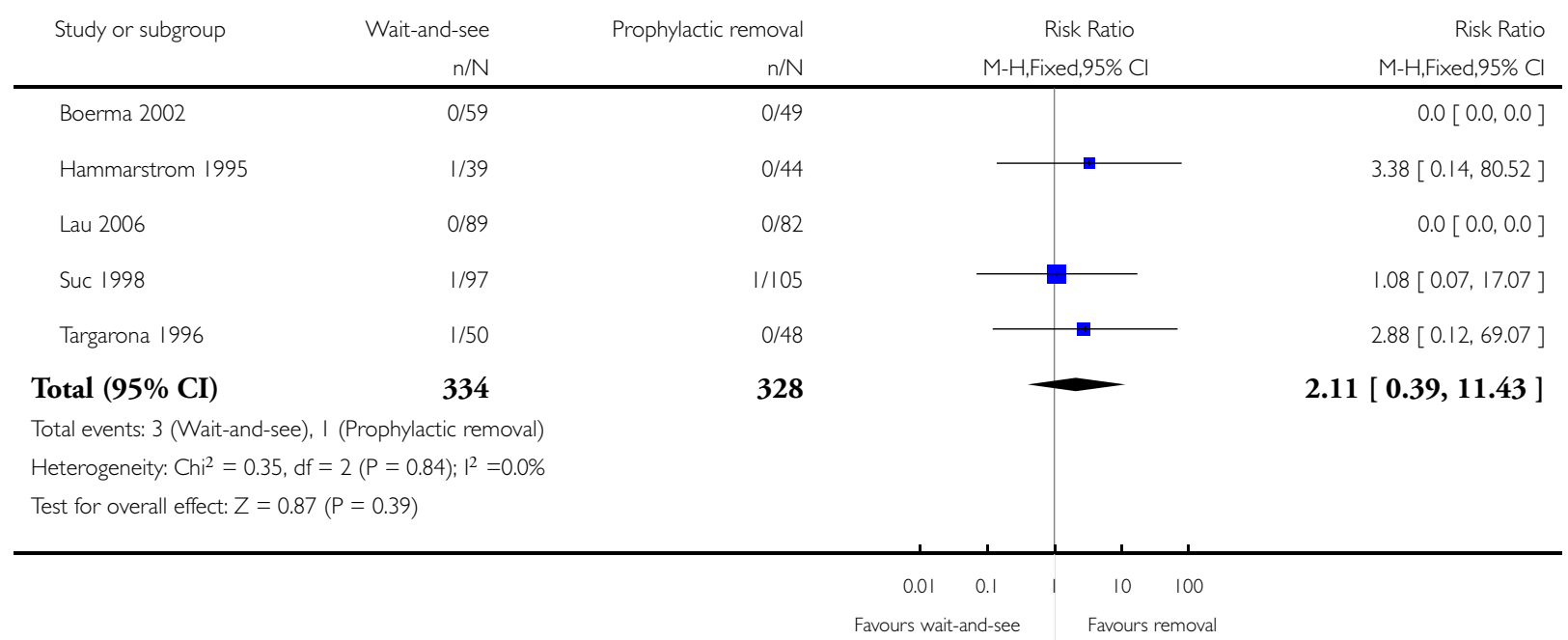


Analysis I.4. Comparison I Wait-and-see versus prophylactic cholecystectomy, Outcome 4 Recurrent jaundice or cholangitis.

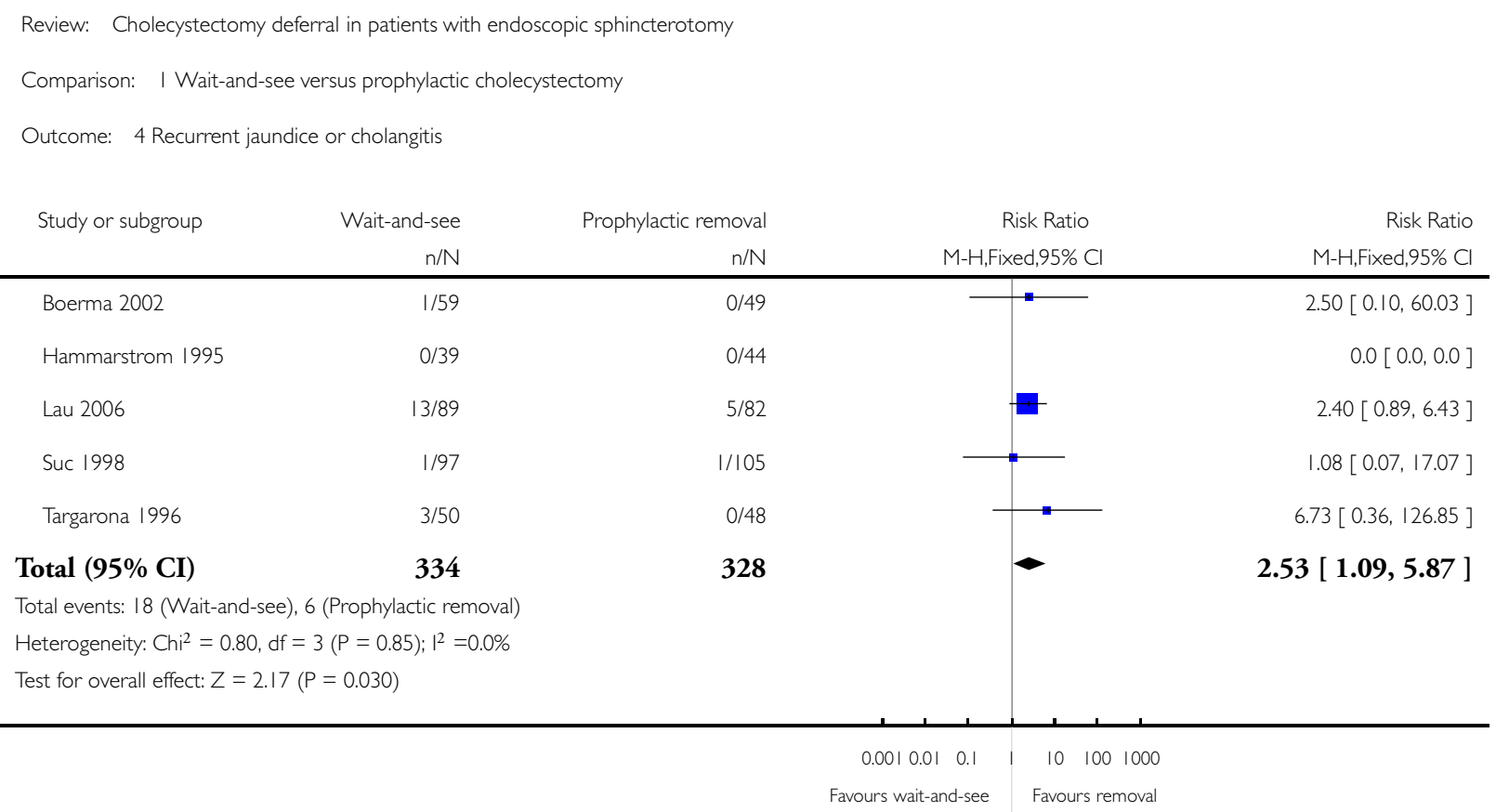


Analysis I.5. Comparison I Wait-and-see versus prophylactic cholecystectomy, Outcome 5 Major adverse events.

Review: Cholecystectomy deferral in patients with endoscopic sphincterotomy

Comparison: I Wait-and-see versus prophylactic cholecystectomy

Outcome: 5 Major adverse events

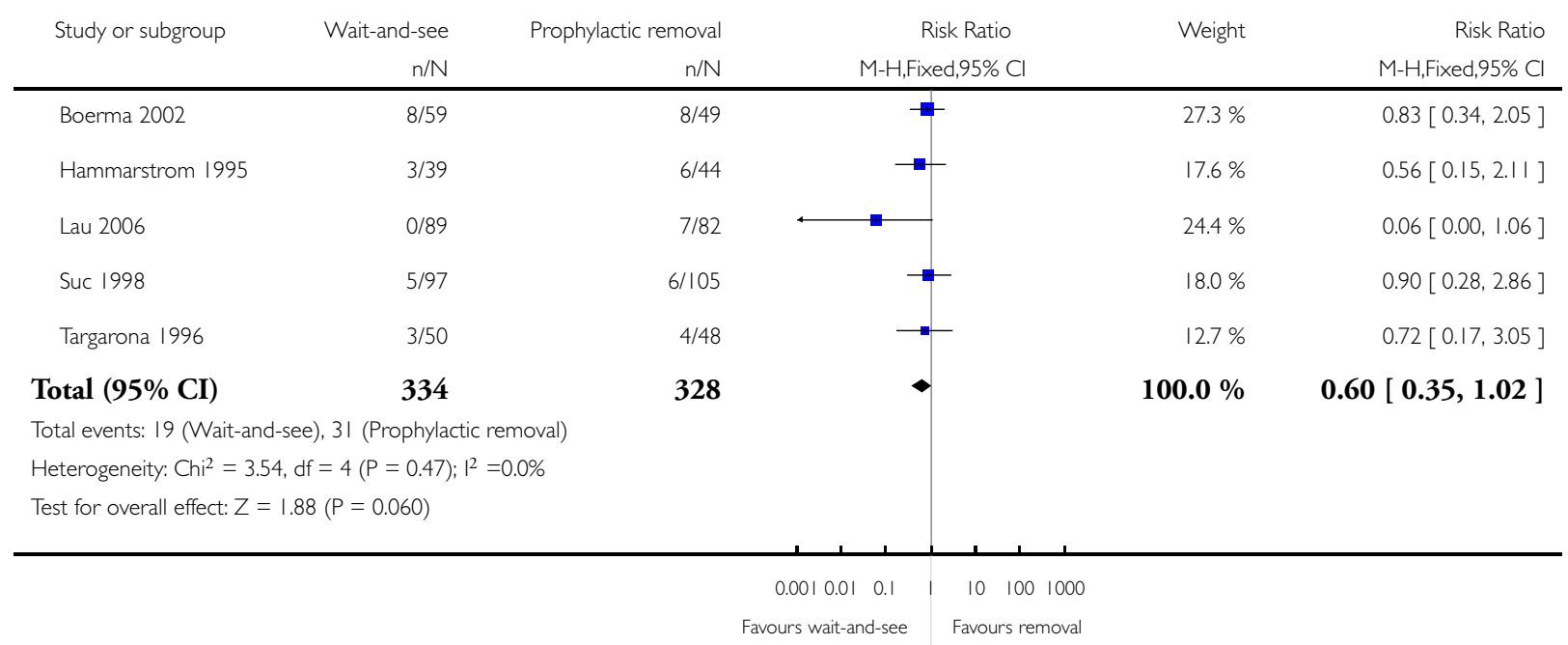


Analysis I.6. Comparison I Wait-and-see versus prophylactic cholecystectomy, Outcome 6 Minor adverse events.

Review: Cholecystectomy deferral in patients with endoscopic sphincterotomy

Comparison: I Wait-and-see versus prophylactic cholecystectomy

Outcome: 6 Minor adverse events

\begin{tabular}{|c|c|c|c|c|c|}
\hline \multirow[t]{2}{*}{ Study or subgroup } & Wait-and-see & Prophylactic removal & Risk Ratio & Weight & Risk Ratio \\
\hline & $n / N$ & $\mathrm{n} / \mathrm{N}$ & M-H,Fixed,95\% Cl & & M-H,Fixed,95\% Cl \\
\hline Boerma 2002 & $5 / 59$ & $3 / 49$ & $\rightarrow$ & $13.7 \%$ & $1.38[0.35,5.50]$ \\
\hline Hammarstrom 1995 & $4 / 39$ & $6 / 44$ & $\rightarrow-$ & $23.6 \%$ & $0.75[0.23,2.47]$ \\
\hline Lau 2006 & $1 / 89$ & $2 / 82$ & -1 & $8.7 \%$ & $0.46[0.04,4.99]$ \\
\hline Suc 1998 & 0/97 & $5 / 105$ & $\because-$ & $22.1 \%$ & $0.10[0.01,1.76]$ \\
\hline Targarona 1996 & $0 / 50$ & $7 / 48$ & $\rightarrow$ & $32.0 \%$ & $0.06[0.00,1.09]$ \\
\hline Total (95\% CI) & 334 & 328 & - & $100.0 \%$ & $0.45[0.22,0.91]$ \\
\hline \multicolumn{6}{|c|}{ Total events: 10 (Wait-and-see), 23 (Prophylactic removal) } \\
\hline \multicolumn{6}{|c|}{ Heterogeneity: Chi $^{2}=6.16, d f=4(P=0.19) ; 1^{2}=35 \%$} \\
\hline \multicolumn{6}{|c|}{ Test for overall effect: $Z=2.24(P=0.025)$} \\
\hline
\end{tabular}

$0.0010 .010 .1 \quad 1 \quad 10 \quad 100 \quad 1000$

Favours wait-and-see Favours removal 
Analysis I.7. Comparison I Wait-and-see versus prophylactic cholecystectomy, Outcome 7 Additional cholangiography (ERCP or PTC).

Review: Cholecystectomy deferral in patients with endoscopic sphincterotomy

Comparison: I Wait-and-see versus prophylactic cholecystectomy

Outcome: 7 Additional cholangiography (ERCP or PTC)

\begin{tabular}{|c|c|c|c|c|c|}
\hline \multirow[t]{2}{*}{ Study or subgroup } & Wait-and-see & Prophylactic removal & Risk Ratio & Weight & Risk Ratio \\
\hline & $\mathrm{n} / \mathrm{N}$ & $\mathrm{n} / \mathrm{N}$ & M-H,Fixed,95\% Cl & & M-H,Fixed,95\% Cl \\
\hline Boerma 2002 & $6 / 59$ & $0 / 49$ & & $3.8 \%$ & $10.83[0.63,187.63]$ \\
\hline Hammarstrom 1995 & $5 / 39$ & $6 / 44$ & & $38.9 \%$ & $0.94[0.31,2.84]$ \\
\hline Lau 2006 & $16 / 89$ & $0 / 82$ & & $3.6 \%$ & $30.43[1.86,499.28]$ \\
\hline Suc 1998 & $6 / 97$ & $6 / 105$ & 1 & $39.7 \%$ & $1.08[0.36,3.24]$ \\
\hline Targarona 1996 & $1 / 50$ & $2 / 48$ & $\rightarrow-$ & $14.1 \%$ & $0.48[0.04,5.12]$ \\
\hline Total (95\% CI) & 334 & 328 & - & $100.0 \%$ & $2.36[1.29,4.32]$ \\
\hline \multicolumn{6}{|c|}{ Total events: 34 (Wait-and-see), 14 (Prophylactic removal) } \\
\hline \multicolumn{6}{|c|}{ Heterogeneity: Chi $^{2}=10.65, d f=4(P=0.03) ; 1^{2}=62 \%$} \\
\hline \multicolumn{6}{|c|}{ Test for overall effect: $Z=2.79(P=0.0053)$} \\
\hline
\end{tabular}


Analysis I.8. Comparison I Wait-and-see versus prophylactic cholecystectomy, Outcome 8 Difficult cholecystectomy.

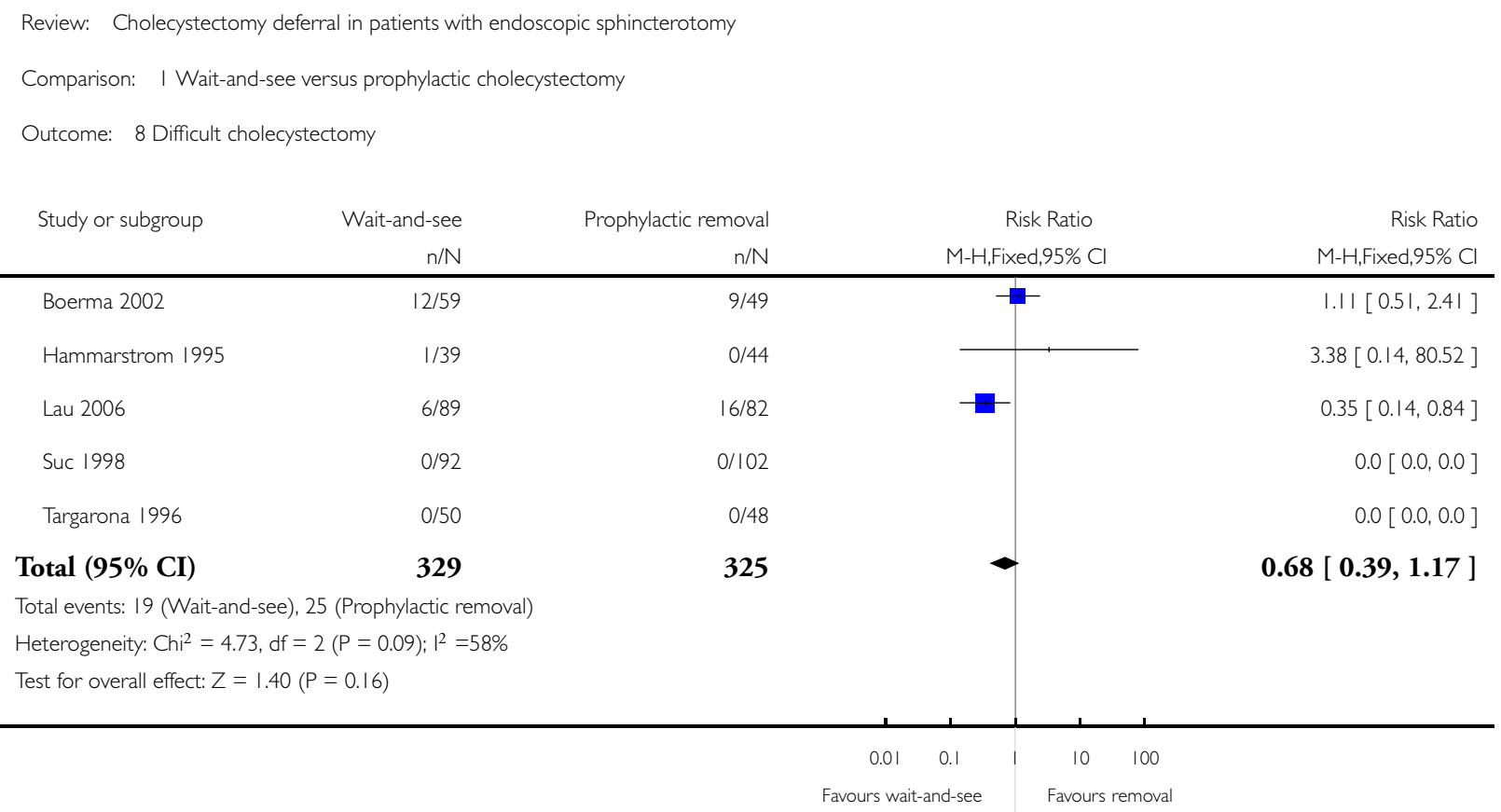




\section{Analysis 2.I. Comparison 2 Stratified by method of cholecystectomy, Outcome I Mortality.}

Review: Cholecystectomy deferral in patients with endoscopic sphincterotomy

Comparison: 2 Stratified by method of cholecystectomy

Outcome: I Mortality

Study or subgroup $\quad$ Wait-and-see $\quad$ Prophylactic removal $\quad$ Risk Ratio $\quad$ Weight

$n / N$
M-H,Fixed,95\% Cl M-H,Fixed,95\% Cl

I Open cholecystectomy \% common bile duct exploration

Hammarstrom 1995

14/39

Suc 1998

I/97

$5 / 44$

Targarona 1996

$10 / 50$

186

Subtotal (95\% CI)

Total events: 25 (Wait-and-see), 14 (Prophylactic removal)

Heterogeneity: $\mathrm{Chi}^{2}=2.45, \mathrm{df}=2(P=0.29) ; 1^{2}=18 \%$

Test for overall effect: $Z=2.05(P=0.040)$

2 Laparoscopic cholecystectomy after sphincterotomy Boerma 2002

1/59

Lau 2006

$19 / 89$

148

Subtotal (95\% CI)

Total events: 20 (Wait-and-see), 12 (Prophylactic removal)

Heterogeneity: Chi $^{2}=0.20, \mathrm{df}=\mathrm{I}(\mathrm{P}=0.65) ; \mathrm{I}^{2}=0.0 \%$

Test for overall effect: $Z=1.26(P=0.21)$

Total (95\% CI)

334

$1 / 105$

$\underset{-}{-}$

| $1 / 82$

Total events: 45 (Wait-and-see), 26 (Prophylactic removal)

Heterogeneity: $\mathrm{Chi}^{2}=2.78, \mathrm{df}=4(\mathrm{P}=0.60) ; \mathrm{I}^{2}=0.0 \%$

Test for overall effect: $Z=2.37(P=0.018)$
$8 / 48$

197

$4.1 \%$

$0.83[0.05,12.94]$

$43.4 \%$

$1.59[0.81,3.14]$

131

$47.6 \%$

$1.53[0.79,2.94]$

$17.8 \%$

$3.16[1.25,7.97]$

$3.6 \% \quad 1.08[0.07,17.07]$

$31.0 \%$

$1.20[0.52,2.78]$

$52.4 \%$

$1.86[1.03,3.35]$

328

$100.0 \%$

$1.70[1.10,2.64]$ 
Analysis 2.2. Comparison 2 Stratified by method of cholecystectomy, Outcome 2 Biliary pain or cholecystitis.

Review: Cholecystectomy deferral in patients with endoscopic sphincterotomy

Comparison: 2 Stratified by method of cholecystectomy

Outcome: 2 Biliary pain or cholecystitis

\begin{tabular}{|c|c|c|c|c|c|}
\hline \multirow[t]{2}{*}{ Study or subgroup } & Wait-and-see & Prophylactic removal & \multirow{2}{*}{$\begin{array}{c}\text { Risk Ratio } \\
\text { M-H,Fixed,95\% Cl }\end{array}$} & \multirow[t]{2}{*}{ Weight } & \multirow{2}{*}{$\begin{array}{r}\text { Risk Ratio } \\
\text { M-H,Fixed,95\% Cl }\end{array}$} \\
\hline & $\mathrm{n} / \mathrm{N}$ & $\mathrm{n} / \mathrm{N}$ & & & \\
\hline \multicolumn{6}{|c|}{ I Open cholecystectomy \% common bile duct exploration } \\
\hline Hammarstrom 1995 & $11 / 39$ & $0 / 44$ & & $13.2 \%$ & $25.88[1.57,425.17]$ \\
\hline Suc 1998 & $4 / 92$ & $0 / 102$ & & $13.4 \%$ & $9.97[0.54,182.66]$ \\
\hline Targarona 1996 & $5 / 50$ & $1 / 48$ & $\rightarrow$ & $28.7 \%$ & $4.80[0.58,39.60]$ \\
\hline Subtotal (95\% CI) & 181 & 194 & & $55.3 \%$ & $11.09[2.69,45.79]$ \\
\hline \multicolumn{6}{|c|}{ Total events: 20 (Wait-and-see), I (Prophylactic removal) } \\
\hline \multicolumn{6}{|c|}{ Heterogeneity: $\mathrm{Chi}^{2}=0.96, \mathrm{df}=2(P=0.62) ; \mathrm{I}^{2}=0.0 \%$} \\
\hline \multicolumn{6}{|c|}{ Test for overall effect: $Z=3.33(P=0.00088)$} \\
\hline \multicolumn{6}{|c|}{2 Laparoscopic cholecystectomy after spincterotomy } \\
\hline Boerma 2002 & $25 / 59$ & $0 / 49$ & $\mp$ & $15.4 \%$ & $42.50[2.65,680.67]$ \\
\hline Lau 2006 & $7 / 89$ & $1 / 82$ & $=$ & $29.3 \%$ & $6.45[0.81,51.30]$ \\
\hline Subtotal (95\% CI) & 148 & 131 & & $44.7 \%$ & $18.84[3.66,97.00]$ \\
\hline \multicolumn{6}{|c|}{ Total events: 32 (Wait-and-see), I (Prophylactic removal) } \\
\hline \multicolumn{6}{|c|}{ Heterogeneity: Chi $^{2}=1.36, d f=|(P=0.24) ;|^{2}=26 \%$} \\
\hline \multicolumn{6}{|c|}{ Test for overall effect: $Z=3.5 \mathrm{I}(\mathrm{P}=0.00044)$} \\
\hline Total $(95 \% \mathrm{CI})$ & 329 & 325 & 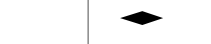 & $100.0 \%$ & $14.56[4.95,42.78]$ \\
\hline \multicolumn{6}{|c|}{ Total events: 52 (Wait-and-see), 2 (Prophylactic removal) } \\
\hline \multicolumn{6}{|c|}{ Heterogeneity: $\mathrm{Chi}^{2}=2.45, \mathrm{df}=4(\mathrm{P}=0.65) ;\left.\right|^{2}=0.0 \%$} \\
\hline Test for overall effect: $Z=$ & $(P<0.00001)$ & & & & \\
\hline
\end{tabular}

$\begin{array}{lllllllll}0.001 & 0.01 & 0.1 & 1 & 10 & 100 & 1000\end{array}$

Favours wait-and-see Favours removal 
Analysis 2.3. Comparison 2 Stratified by method of cholecystectomy, Outcome 3 Pancreatitis.

Review: Cholecystectomy deferral in patients with endoscopic sphincterotomy

Comparison: 2 Stratified by method of cholecystectomy

Outcome: 3 Pancreatitis

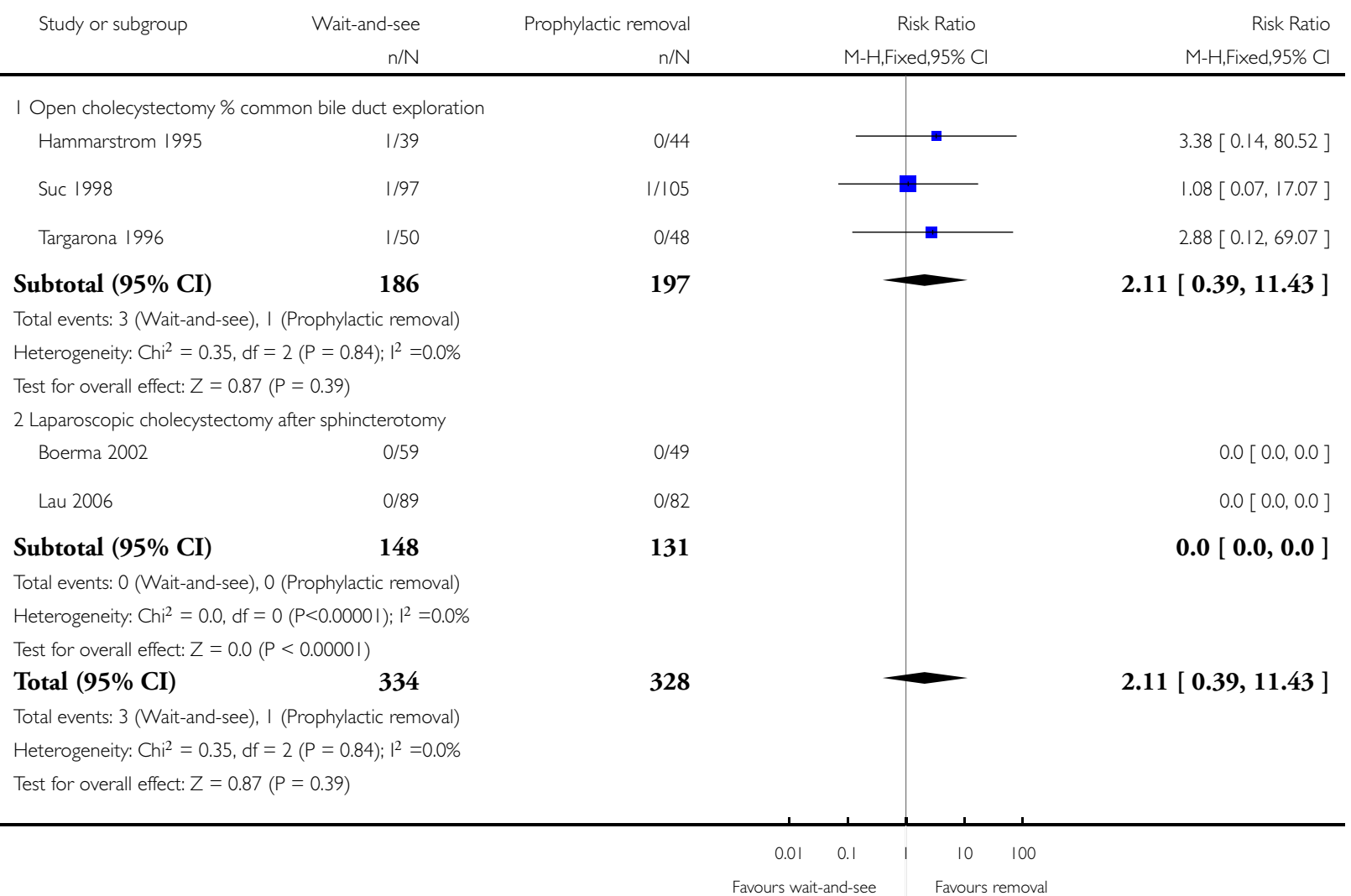


Analysis 2.4. Comparison 2 Stratified by method of cholecystectomy, Outcome 4 Recurrent jaundice or cholangitis.

Review: Cholecystectomy deferral in patients with endoscopic sphincterotomy

Comparison: 2 Stratified by method of cholecystectomy

Outcome: 4 Recurrent jaundice or cholangitis

\begin{tabular}{|c|c|c|c|c|}
\hline \multirow[t]{2}{*}{ Study or subgroup } & Wait-and-see & Prophylactic removal & \multirow{2}{*}{$\begin{array}{c}\text { Risk Ratio } \\
\text { M-H,Fixed,95\% Cl }\end{array}$} & \multirow{2}{*}{$\begin{array}{r}\text { Risk Ratio } \\
\text { M-H,Fixed,95\% Cl }\end{array}$} \\
\hline & $\mathrm{n} / \mathrm{N}$ & $\mathrm{n} / \mathrm{N}$ & & \\
\hline \multicolumn{5}{|c|}{ I Open cholecystectomy \% common bile duct exploration } \\
\hline Hammarstrom 1995 & 0/39 & $0 / 44$ & & $0.0[0.0,0.0]$ \\
\hline Suc 1998 & 1/97 & $1 / 105$ & & $1.08[0.07,17.07]$ \\
\hline Targarona 1996 & $3 / 50$ & 0/48 & & $6.73[0.36,126.85]$ \\
\hline Subtotal (95\% CI) & 186 & 197 & & $3.04[0.47,19.49]$ \\
\hline \multicolumn{5}{|c|}{ Total events: 4 (Wait-and-see), I (Prophylactic removal) } \\
\hline \multicolumn{5}{|c|}{ Heterogeneity: $\mathrm{Chi}^{2}=0.82, \mathrm{df}=|(P=0.37) ;|^{2}=0.0 \%$} \\
\hline \multicolumn{5}{|c|}{ Test for overall effect: $Z=1.17(P=0.24)$} \\
\hline \multicolumn{5}{|c|}{2 Laparoscopic cholecystectomy after sphincterotomy } \\
\hline Boerma 2002 & $1 / 59$ & 0/49 & + & $2.50[0.10,60.03]$ \\
\hline Lau 2006 & $13 / 89$ & $5 / 82$ & & $2.40[0.89,6.43]$ \\
\hline Subtotal (95\% CI) & 148 & 131 & $\mathbf{r}$ & $2.41[0.94,6.18]$ \\
\hline \multicolumn{5}{|c|}{ Total events: I4 (Wait-and-see), 5 (Prophylactic removal) } \\
\hline \multicolumn{5}{|c|}{ Heterogeneity: $\mathrm{Chi}^{2}=0.00, \mathrm{df}=|(P=0.98) ;|^{2}=0.0 \%$} \\
\hline \multicolumn{5}{|c|}{ Test for overall effect: $Z=1.82(P=0.068)$} \\
\hline Total $(95 \%$ CI $)$ & 334 & 328 & - & $2.53[1.09,5.87]$ \\
\hline \multicolumn{5}{|c|}{ Total events: 18 (Wait-and-see), 6 (Prophylactic removal) } \\
\hline \multicolumn{5}{|c|}{ Heterogeneity: $\mathrm{Chi}^{2}=0.80, \mathrm{df}=3(\mathrm{P}=0.85) ; \mathrm{I}^{2}=0.0 \%$} \\
\hline \multicolumn{5}{|c|}{ Test for overall effect: $Z=2.17(P=0.030)$} \\
\hline
\end{tabular}


Analysis 2.5. Comparison 2 Stratified by method of cholecystectomy, Outcome 5 Major adverse events.

Review: Cholecystectomy deferral in patients with endoscopic sphincterotomy

Comparison: 2 Stratified by method of cholecystectomy

Outcome: 5 Major adverse events

Study or subgroup $\quad$ Wait-and-see Prophylactic removal $\quad$ Risk Ratio $\quad$ Weight

$n / N \quad n / N$

$\mathrm{n} / \mathrm{N} \quad \mathrm{M}-\mathrm{H}$, Fixed, $95 \% \mathrm{Cl}$

M-H,Fixed,95\% Cl

I Open cholecystectomy \% common bile duct exploration

Hammarstrom 1995

$6 / 44$

Suc 1998

$5 / 97$

Targarona 1996

$3 / 50$

186

Subtotal (95\% CI)

Total events: I I (Wait-and-see), 16 (Prophylactic removal)

Heterogeneity: $\mathrm{Chi}^{2}=0.28, \mathrm{df}=2(\mathrm{P}=0.87) ; \mathrm{I}^{2}=0.0 \%$

Test for overall effect: $Z=0.83(P=0.41)$

2 Laparoscopic cholecystectomy after sphincterotomy

Boerma 2002

$8 / 59$

Lau 2006

0/89

Subtotal (95\% CI)

148

Total events: 8 (Wait-and-see), 15 (Prophylactic removal)

Heterogeneity: Chi $^{2}=3.50, \mathrm{df}=1(P=0.06) ; \mathrm{I}^{2}=71 \%$

Test for overall effect: $Z=1.86(P=0.063)$

Total (95\% CI)

334

Total events: 19 (Wait-and-see), 3 I (Prophylactic removal)

Heterogeneity: $\mathrm{Chi}^{2}=3.54, \mathrm{df}=4(\mathrm{P}=0.47) ; \mathrm{I}^{2}=0.0 \%$

Test for overall effect: $Z=1.88(P=0.060)$

$6 / 105$

$4 / 48$

197

131

328
7

$\rightarrow$

$-17.6 \%$

$-18.0 \%$
$-\quad 17.6 \%$

$12.7 \%$

$0.56[0.15,2.11]$

$17.6 \%$

$0.90[0.28,2.86]$

$0.72[0.17,3.05]$

$48.3 \%$

0.73 [ $0.35,1.53$ ]

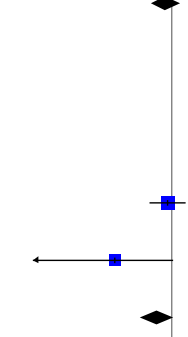

$27.3 \%$

$0.83[0.34,2.05]$

$24.4 \%$

$0.06[0.00,1.06]$

$51.7 \%$

$0.47[0.21,1.04$ ]

$\checkmark$

$100.0 \%$

$0.60[0.35,1.02]$

$0.0010 .01 \quad 0.1 \quad 1 \quad 10 \quad 100 \quad 1000$

Favours wait-and-see Favours removal 
Analysis 2.6. Comparison 2 Stratified by method of cholecystectomy, Outcome 6 Minor adverse events.

Review: Cholecystectomy deferral in patients with endoscopic sphincterotomy

Comparison: 2 Stratified by method of cholecystectomy

Outcome: 6 Minor adverse events

\begin{tabular}{|c|c|c|c|c|c|}
\hline \multirow[t]{2}{*}{ Study or subgroup } & Wait-and-see & Prophylactic removal & \multirow{2}{*}{$\begin{array}{c}\text { Risk Ratio } \\
\text { M-H,Fixed,95\% Cl }\end{array}$} & \multirow[t]{2}{*}{ Weight } & \multirow{2}{*}{$\begin{array}{r}\text { Risk Ratio } \\
\mathrm{M}-\mathrm{H}, \text { Fixed,95\% Cl }\end{array}$} \\
\hline & $n / N$ & $\mathrm{n} / \mathrm{N}$ & & & \\
\hline \multicolumn{6}{|c|}{ I Open cholecystectomy \% common bile duct exploration } \\
\hline Hammarstrom 1995 & $4 / 39$ & $6 / 44$ & $\rightarrow$ & $23.6 \%$ & $0.75[0.23,2.47]$ \\
\hline Suc 1998 & 0/97 & $5 / 105$ & $\longrightarrow$ & $22.1 \%$ & $0.10[0.01,1.76]$ \\
\hline Targarona 1996 & $0 / 50$ & $7 / 48$ & 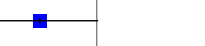 & $32.0 \%$ & $0.06[0.00,1.09]$ \\
\hline Subtotal $(95 \% \mathrm{CI})$ & 186 & 197 & $<$ & $77.6 \%$ & $0.28[0.11,0.73]$ \\
\hline \multicolumn{6}{|c|}{ Total events: 4 (Wait-and-see), I8 (Prophylactic removal) } \\
\hline \multicolumn{6}{|c|}{ Heterogeneity: $\mathrm{Chi}^{2}=4.17, \mathrm{df}=2(\mathrm{P}=0.12) ; \mathrm{I}^{2}=52 \%$} \\
\hline \multicolumn{6}{|c|}{ Test for overall effect: $Z=2.62(P=0.0087)$} \\
\hline \multicolumn{6}{|c|}{2 Laparoscopic cholecystectomy after sphincterotomy } \\
\hline Boerma 2002 & $5 / 59$ & $3 / 49$ & 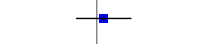 & $13.7 \%$ & $1.38[0.35,5.50]$ \\
\hline Lau 2006 & $1 / 89$ & $2 / 82$ & - & $8.7 \%$ & $0.46[0.04,4.99]$ \\
\hline Subtotal $(95 \% \mathrm{CI})$ & 148 & 131 & & $22.4 \%$ & $1.03[0.32,3.27]$ \\
\hline \multicolumn{6}{|c|}{ Total events: 6 (Wait-and-see), 5 (Prophylactic removal) } \\
\hline \multicolumn{6}{|c|}{ Heterogeneity: $\mathrm{Ch}^{2}=0.62, \mathrm{df}=\mathrm{I}(\mathrm{P}=0.43) ; \mathrm{I}^{2}=0.0 \%$} \\
\hline \multicolumn{6}{|c|}{ Test for overall effect: $Z=0.04(P=0.97)$} \\
\hline Total $(95 \% \mathrm{CI})$ & 334 & 328 & - & $100.0 \%$ & $0.45[0.22,0.91]$ \\
\hline \multicolumn{6}{|c|}{ Total events: 10 (Wait-and-see), 23 (Prophylactic removal) } \\
\hline \multicolumn{6}{|c|}{ Heterogeneity: $C h i^{2}=6.16, d f=4(P=0.19) ; 1^{2}=35 \%$} \\
\hline Test for overall effect: $Z=$ & $(P=0.025)$ & & & & \\
\hline
\end{tabular}

$0.0010 .01 \quad 0.1 \quad 1 \quad 10 \quad 100 \quad 1000$

Favours wait-and-see Favours removal 


\section{Analysis 2.7. Comparison 2 Stratified by method of cholecystectomy, Outcome 7 Additional cholangiography (ERCP or PTC).}

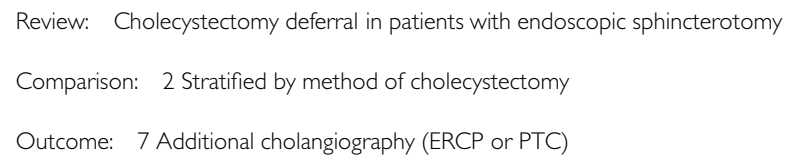

\begin{tabular}{|c|c|c|c|c|c|}
\hline \multirow[t]{2}{*}{ Study or subgroup } & Wait-and-see & Prophylactic removal & \multirow{2}{*}{$\begin{array}{c}\text { Risk Ratio } \\
\text { M-H,Fixed,95\% Cl }\end{array}$} & \multirow[t]{2}{*}{ Weight } & \multirow{2}{*}{$\begin{array}{r}\text { Risk Ratio } \\
\text { M-H,Fixed,95\% Cl }\end{array}$} \\
\hline & $n / N$ & $\mathrm{n} / \mathrm{N}$ & & & \\
\hline \multicolumn{6}{|c|}{ I Open cholecystectomy \% common bile duct exploration } \\
\hline Hammarstrom 1995 & $5 / 39$ & $6 / 44$ & & $38.9 \%$ & $0.94[0.31,2.84]$ \\
\hline Suc 1998 & $6 / 97$ & $6 / 105$ & & $39.7 \%$ & $1.08[0.36,3.24]$ \\
\hline Targarona 1996 & $1 / 50$ & $2 / 48$ & 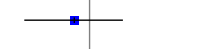 & $14.1 \%$ & $0.48[0.04,5.12]$ \\
\hline Subtotal (95\% CI) & 186 & 197 & 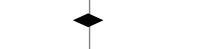 & $92.7 \%$ & $0.93[0.45,1.94]$ \\
\hline \multicolumn{6}{|c|}{ Total events: 12 (Wait-and-see), 14 (Prophylactic removal) } \\
\hline \multicolumn{6}{|c|}{ Heterogeneity: $\mathrm{Chi}^{2}=0.37, \mathrm{df}=2(\mathrm{P}=0.83) ; \mathrm{I}^{2}=0.0 \%$} \\
\hline \multicolumn{6}{|c|}{ Test for overall effect: $Z=0.19(P=0.85)$} \\
\hline \multicolumn{6}{|c|}{2 Laparoscopic cholecystectomy after sphincterotomy } \\
\hline Boerma 2002 & $6 / 59$ & $0 / 49$ & & $3.8 \%$ & $10.83[0.63,187.63]$ \\
\hline Lau 2006 & $16 / 89$ & $0 / 82$ & 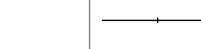 & $3.6 \%$ & $30.43[1.86,499.28]$ \\
\hline Subtotal (95\% CI) & 148 & 131 & & $7.3 \%$ & $20.40[2.82,147.51]$ \\
\hline \multicolumn{6}{|c|}{ Total events: 22 (Wait-and-see), 0 (Prophylactic removal) } \\
\hline \multicolumn{6}{|c|}{ Heterogeneity: $\mathrm{Chi}^{2}=0.27, \mathrm{df}=\mathrm{I}(\mathrm{P}=0.60) ; \mathrm{I}^{2}=0.0 \%$} \\
\hline \multicolumn{6}{|c|}{ Test for overall effect: $Z=2.99(P=0.0028)$} \\
\hline Total (95\% CI) & 334 & 328 & 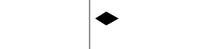 & $100.0 \%$ & $2.36[1.29,4.32]$ \\
\hline \multicolumn{6}{|c|}{ Total events: 34 (Wait-and-see), 14 (Prophylactic removal) } \\
\hline \multicolumn{6}{|c|}{ Heterogeneity: $\mathrm{Chi}^{2}=10.65, \mathrm{df}=4(\mathrm{P}=0.03) ; \mathrm{I}^{2}=62 \%$} \\
\hline Test for overall effect: $Z=$ & $(P=0.0053)$ & & & & \\
\hline
\end{tabular}




\section{Analysis 2.8. Comparison 2 Stratified by method of cholecystectomy, Outcome 8 Difficult cholecystectomy.}

Review: Cholecystectomy deferral in patients with endoscopic sphincterotomy

Comparison: 2 Stratified by method of cholecystectomy

Outcome: 8 Difficult cholecystectomy

Study or subgroup Wait-and-see $\mathrm{n} / \mathrm{N}$

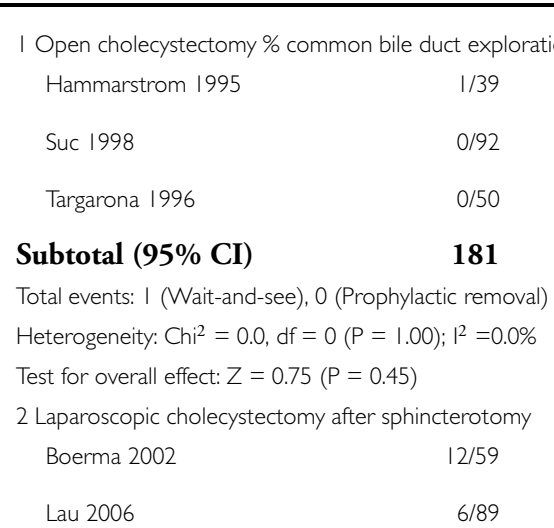

Subtotal (95\% CI)

148

Total events: 18 (Wait-and-see), 25 (Prophylactic removal)

Heterogeneity: Chi $^{2}=3.78, d f=I(P=0.05) ; I^{2}=74 \%$

Test for overall effect: $Z=1.61(P=0.11)$

Total (95\% CI)

329

Total events: 19 (Wait-and-see), 25 (Prophylactic removal)

Heterogeneity: $\mathrm{Chi}^{2}=4.73, \mathrm{df}=2(\mathrm{P}=0.09) ; \mathrm{I}^{2}=58 \%$

Test for overall effect: $Z=1.40(P=0.16)$
Prophylactic removal

Risk Ratio

Risk Ratio

$\mathrm{n} / \mathrm{N}$ M-H,Fixed,95\% Cl

M-H,Fixed,95\% Cl

$3.38[0.14,80.52]$

$0.0[0.0,0.0]$

$0.0[0.0,0.0]$

0/48

194

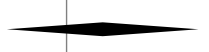

$3.38[0.14,80.52$ ]

I.I I [0.5।, 2.4I ]

$0.35[0.14,0.84]$

$16 / 82$

131

$0.63[0.36,1.10$ ]

325

$0.68[0.39,1.17]$ 


\section{Analysis 3.I. Comparison 3 Stratified by patient ASA class, Outcome I Mortality.}

Review: Cholecystectomy deferral in patients with endoscopic sphincterotomy

Comparison: 3 Stratified by patient ASA class

Outcome: I Mortality

Study or subgroup Wait-and-see Prophylactic remova

I Studies with inclusion of high-risk patients (ASA IV or V)

$\mathrm{n} / \mathrm{N}$

Risk Ratio

Weight

Risk Ratio

$5 / 44$

M-H,Fixed,95\% Cl

M-H,Fixed,95\% Cl

Hammarstrom 1995

14/39

Suc 1998

1/97

$1 / 105$

Targarona 1996

$10 / 50$

Subtotal (95\% CI)

186

Total events: 25 (Wait-and-see), 14 (Prophylactic removal)

Heterogeneity: $\mathrm{Chi}^{2}=2.45, \mathrm{df}=2(\mathrm{P}=0.29) ; \mathrm{I}^{2}=18 \%$

Test for overall effect: $Z=2.05(P=0.040)$

2 Studies with exclusion of high-risk patients (ASA IV or V) Boerma 2002

Lau 2006

$19 / 89$

148

Subtotal (95\% CI)

Total events: 20 (Wait-and-see), 12 (Prophylactic removal)
Heterogeneity: $\mathrm{Chi}^{2}=0.20, \mathrm{df}=\mid(\mathrm{P}=0.65): \mathrm{I}^{2}=0.0 \%$

Test for overall effect: $Z=1.26(P=0.21)$

Total (95\% CI)

334

$\frac{\square}{-}$

$17.8 \%$

$3.16[1.25,7.97]$

Total events: 45 (Wait-and-see), 26 (Prophylactic removal)

Heterogeneity: $\mathrm{Chi}^{2}=2.78, \mathrm{df}=4(\mathrm{P}=0.60) ; \mathrm{I}^{2}=0.0 \%$

Test for overall effect: $Z=2.37(P=0.018)$
$8 / 48$

197

328

$3.6 \%$

$31.0 \%$

$1.08[0.07,17.07]$

$1.20[0.52,2.78]$

$52.4 \%$

$1.86[1.03,3.35]$

$4.1 \%$

$0.83[0.05,12.94]$

$43.4 \%$

I.59 [0.8।, 3.14]

131

$47.6 \%$

$1.53[0.79,2.94$ ]

$100.0 \%$

$1.70[1.10,2.64]$ 
Analysis 3.2. Comparison 3 Stratified by patient ASA class, Outcome 2 Biliary pain or cholecystitis.

Review: Cholecystectomy deferral in patients with endoscopic sphincterotomy

Comparison: 3 Stratified by patient ASA class

Outcome: 2 Biliary pain or cholecystitis

Study or subgroup Wait-and-see Prophylactic removal $\mathrm{n} / \mathrm{N}$

I Studies with inclusion of high-risk patients (ASA IV or V)

Hammarstrom $1995 \quad$ | I/39

Suc 1998

Targarona 1996

Subtotal (95\% CI)

$4 / 92$

$5 / 50$

181

Total events: 20 (Wait-and-see), I (Prophylactic removal)

Heterogeneity: $\mathrm{Chi}^{2}=0.96, \mathrm{df}=2(\mathrm{P}=0.62) ; \mathrm{I}^{2}=0.0 \%$

Test for overall effect: $Z=3.33(P=0.00088)$

2 Studies with exclusion of high-risk patients (ASA IV or V)

Boerma 2002

$25 / 59$

Lau 2006

$7 / 89$

148

Subtotal (95\% CI)

Total events: 32 (Wait-and-see), I (Prophylactic removal)

Test for overall effect: $Z=3.5 \mathrm{I}(\mathrm{P}=0.00044)$

Total (95\% CI)

329

Total events: 52 (Wait-and-see), 2 (Prophylactic removal)

Heterogeneity: $\mathrm{Chi}^{2}=2.45, \mathrm{df}=4(\mathrm{P}=0.65) ; \mathrm{I}^{2}=0.0 \%$

Test for overall effect: $Z=4.87(P<0.0000 I)$ $\mathrm{n} / \mathrm{N}$

131
Risk Ratio M-H,Fixed,95\% C

Weight

Risk Ratio

$25.88[1.57,425.17]$

$13.4 \%$

$9.97[0.54,182.66]$

$28.7 \%$

$4.80[0.58,39.60]$

$55.3 \%$

$11.09[2.69,45.79]$

\section{4}

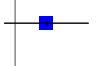

$15.4 \%$

$42.50[2.65,680.67]$

$29.3 \%$ $6.45[0.81,51.30]$

$44.7 \%$

$18.84[3.66,97.00]$

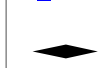

$100.0 \%$

$14.56[4.95,42.78]$ 


\section{Analysis 3.3. Comparison 3 Stratified by patient ASA class, Outcome 3 Pancreatitis.}

Review: Cholecystectomy deferral in patients with endoscopic sphincterotomy

Comparison: 3 Stratified by patient ASA class

Outcome: 3 Pancreatitis

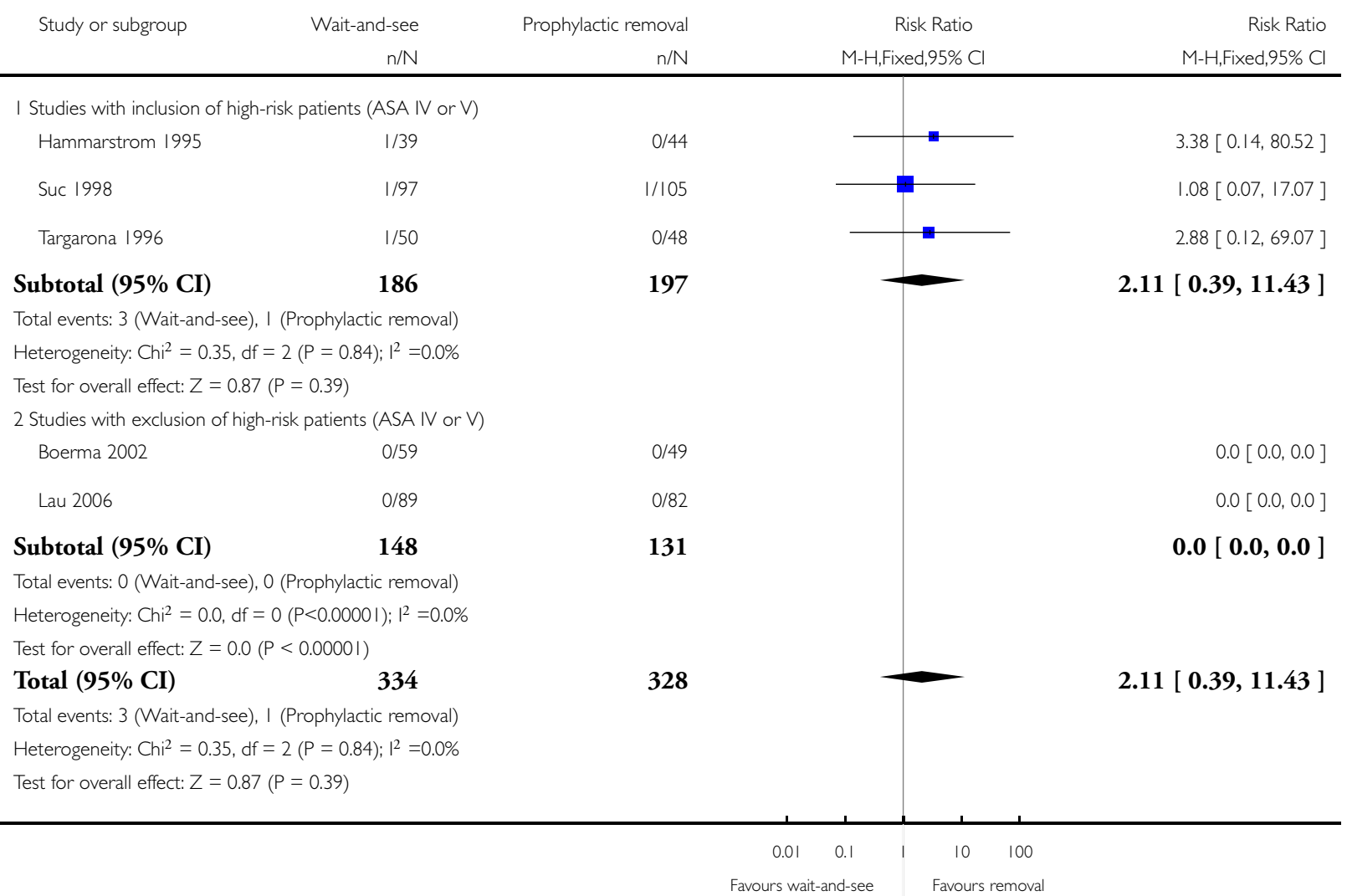


Analysis 3.4. Comparison 3 Stratified by patient ASA class, Outcome 4 Recurrent jaundice or cholangitis.

Review: Cholecystectomy deferral in patients with endoscopic sphincterotomy

Comparison: 3 Stratified by patient ASA class

Outcome: 4 Recurrent jaundice or cholangitis

Study or subgroup Wait-and-see

$\mathrm{n} / \mathrm{N}$

\begin{tabular}{|c|c|}
\hline \multicolumn{2}{|c|}{ I Studies with inclusion of high-risk patients (ASA IV or V) } \\
\hline Hammarstrom 1995 & $0 / 39$ \\
\hline Suc 1998 & $1 / 97$ \\
\hline Targarona 1996 & $3 / 50$ \\
\hline Subtotal $(95 \%$ CI $)$ & 186 \\
\hline \multicolumn{2}{|c|}{ Total events: 4 (Wait-and-see), I (Prophylactic removal) } \\
\hline \multicolumn{2}{|c|}{ Heterogeneity: $\mathrm{Chi}^{2}=0.82, \mathrm{df}=|(P=0.37) ;|^{2}=0.0 \%$} \\
\hline \multicolumn{2}{|c|}{ Test for overall effect: $Z=1.17(P=0.24)$} \\
\hline \multicolumn{2}{|c|}{2 Studies with exclusion of high-risk patients (ASA IV or V) } \\
\hline Boerma 2002 & $1 / 59$ \\
\hline Lau 2006 & $13 / 89$ \\
\hline
\end{tabular}

Subtotal (95\% CI)

148

Total events: I 4 (Wait-and-see), 5 (Prophylactic removal) Heterogeneity: $\mathrm{Chi}^{2}=0.00, \mathrm{df}=\mathrm{I}(\mathrm{P}=0.98) ; \mathrm{I}^{2}=0.0 \%$

Test for overall effect: $Z=1.82(P=0.068)$

Total (95\% CI) 334

Total events: 18 (Wait-and-see), 6 (Prophylactic removal) Heterogeneity: $\mathrm{Chi}^{2}=0.80, \mathrm{df}=3(\mathrm{P}=0.85) ; \mathrm{I}^{2}=0.0 \%$

Test for overall effect: $Z=2.17(P=0.030)$
Prophylactic removal $\mathrm{n} / \mathrm{N}$

Risk Ratio

Risk Ratio M-H,Fixed, $95 \% \mathrm{Cl}$

M-H,Fixed,95\% Cl

$0 / 44$

$1 / 105$

$0 / 48$

197

$\longrightarrow$

$2.40[0.89,6.43]$

$5 / 82$

131

$2.41[0.94,6.18$ ]

328

$2.53[1.09,5.87]$
$2.50[0.10,60.03]$

$0.0[0.0,0.0]$

$1.08[0.07,17.07]$

$6.73[0.36,126.85]$

$3.04[0.47,19.49$ ]

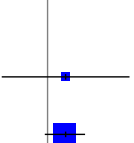

0.0010 .010 .1 
Analysis 3.5. Comparison 3 Stratified by patient ASA class, Outcome 5 Major adverse events.

Review: Cholecystectomy deferral in patients with endoscopic sphincterotomy

Comparison: 3 Stratified by patient ASA class

Outcome: 5 Major adverse events

Study or subgroup $\quad$ Wait-and-see $\quad$ Prophylactic removal $\quad$ Risk Ratio Risk Ratio

$n / N$

$\mathrm{n} / \mathrm{N} \quad \mathrm{M}-\mathrm{H}, \mathrm{Fixed}, 95 \% \mathrm{Cl}$

M-H,Fixed, $95 \% \mathrm{Cl}$

I Studies with inclusion of high-risk patients (ASA IV or V)

Hammarstrom 1995

$6 / 44$

Suc 1998

$5 / 97$

$6 / 105$

Targarona 1996

$3 / 50$

$4 / 48$

186

197

Subtotal (95\% CI)

Total events: I I (Wait-and-see), I 6 (Prophylactic removal)
Heterogeneity: $\mathrm{Chi}^{2}=0.28, \mathrm{df}=2(\mathrm{P}=0.87) ; \mathrm{I}^{2}=0.0 \%$

Test for overall effect: $Z=0.83(P=0.41)$

2 Studies with exclusion of high-risk patients (ASA IV or V) Boerma 2002

Lau 2006

0/89

148

Subtotal (95\% CI)

Total events: 8 (Wait-and-see), I5 (Prophylactic removal)
Heterogeneity: $\mathrm{Chi}^{2}=3.50 \mathrm{df}=|(\mathrm{P}=0.06) ;|^{2}=71 \%$

Test for overall effect: $Z=1.86(P=0.063)$

Total (95\% CI)

334

Total events: 19 (Wait-and-see), 3 I (Prophylactic removal)

Heterogeneity: $\mathrm{Chi}^{2}=3.54, \mathrm{df}=4(\mathrm{P}=0.47) ; \mathrm{I}^{2}=0.0 \%$

Test for overall effect: $Z=1.88(P=0.060)$

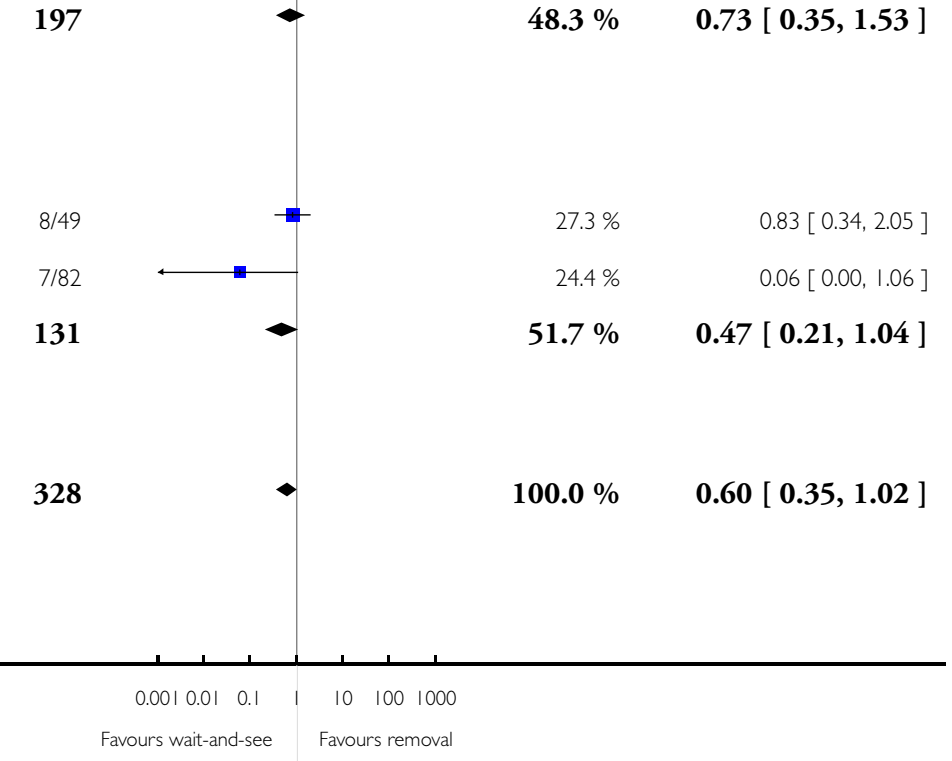




\section{Analysis 3.6. Comparison 3 Stratified by patient ASA class, Outcome 6 Minor adverse events.}

Review: Cholecystectomy deferral in patients with endoscopic sphincterotomy

Comparison: 3 Stratified by patient ASA class

Outcome: 6 Minor adverse events

\begin{tabular}{|c|c|c|c|c|c|}
\hline \multirow[t]{2}{*}{ Study or subgroup } & Wait-and-see & Prophylactic removal & Risk Ratio & \multirow[t]{2}{*}{ Weight } & \multirow{2}{*}{$\begin{array}{r}\text { Risk Ratio } \\
\text { M-H,Fixed,95\% Cl }\end{array}$} \\
\hline & $\mathrm{n} / \mathrm{N}$ & $\mathrm{n} / \mathrm{N}$ & M-H,Fixed,95\% Cl & & \\
\hline \multicolumn{6}{|c|}{ I Studies with inclusion of high-risk patients (ASA IV or V) } \\
\hline Hammarstrom 1995 & $4 / 39$ & $6 / 44$ & $\rightarrow$ & $23.6 \%$ & $0.75[0.23,2.47]$ \\
\hline Suc 1998 & 0/97 & $5 / 105$ & $\longrightarrow$ & $22.1 \%$ & $0.10[0.01,1.76]$ \\
\hline Targarona 1996 & $0 / 50$ & $7 / 48$ & $\longleftarrow$ & $32.0 \%$ & $0.06[0.00,1.09]$ \\
\hline Subtotal (95\% CI) & 186 & 197 & $>$ & $77.6 \%$ & $0.28[0.11,0.73]$ \\
\hline \multicolumn{6}{|c|}{ Total events: 4 (Wait-and-see), I8 (Prophylactic removal) } \\
\hline \multicolumn{6}{|c|}{ Heterogeneity: $\mathrm{Chi}^{2}=4.17, \mathrm{df}=2(\mathrm{P}=0.12) ; \mathrm{I}^{2}=52 \%$} \\
\hline \multicolumn{6}{|c|}{ Test for overall effect: $Z=2.62(P=0.0087)$} \\
\hline \multicolumn{6}{|c|}{2 Studies with exclusion of high-risk patients (ASA IV or V) } \\
\hline Boerma 2002 & $5 / 59$ & $3 / 49$ & $\longrightarrow$ & $13.7 \%$ & $1.38[0.35,5.50]$ \\
\hline Lau 2006 & $1 / 89$ & $2 / 82$ & - & $8.7 \%$ & $0.46[0.04,4.99]$ \\
\hline Subtotal $(95 \% \mathrm{CI})$ & 148 & 131 & $\mathbf{r}$ & $22.4 \%$ & $1.03[0.32,3.27]$ \\
\hline \multicolumn{6}{|c|}{ Total events: 6 (Wait-and-see), 5 (Prophylactic removal) } \\
\hline \multicolumn{6}{|c|}{ Heterogeneity: $\mathrm{Ch}^{2}=0.62, \mathrm{df}=\mathrm{I}(\mathrm{P}=0.43) ; \mathrm{I}^{2}=0.0 \%$} \\
\hline \multicolumn{6}{|c|}{ Test for overall effect: $Z=0.04(P=0.97)$} \\
\hline Total $(95 \%$ CI $)$ & 334 & 328 & 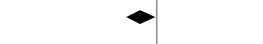 & $100.0 \%$ & $0.45[0.22,0.91]$ \\
\hline \multicolumn{6}{|c|}{ Total events: 10 (Wait-and-see), 23 (Prophylactic removal) } \\
\hline \multicolumn{6}{|c|}{ Heterogeneity: $\mathrm{Chi}^{2}=6.16, \mathrm{df}=4(P=0.19) ; 1^{2}=35 \%$} \\
\hline Test for overall effect: $Z=$ & $(P=0.025)$ & & & & \\
\hline
\end{tabular}

$0.0010 .01 \quad 0.1 \quad 1 \quad 10 \quad 100 \quad 1000$

Favours wait-and-see Favours removal 


\section{Analysis 3.7. Comparison 3 Stratified by patient ASA class, Outcome 7 Additional cholangiography (ERCP or PTC).}

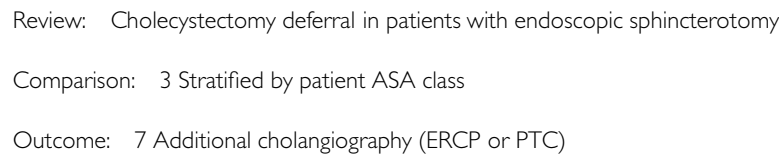

$n / N \quad n / N \quad M-H, F i x e d, 95 \%$ Cl $\quad$ M-H,Fixed,95\% Cl

I Studies with inclusion of high-risk patients (ASA IV or V)

$\begin{array}{lcc}\text { Hammarstrom 1995 } & 5 / 39 & 6 / 44 \\ \text { Suc } 1998 & 6 / 97 & 6 / 105 \\ \text { Targarona 1996 } & 1 / 50 & 2 / 48\end{array}$

\section{Subtotal (95\% CI)}

186

Total events: 12 (Wait-and-see), 14 (Prophylactic removal) Heterogeneity: $\mathrm{Chi}^{2}=0.37, \mathrm{df}=2(\mathrm{P}=0.83) ; \mathrm{I}^{2}=0.0 \%$ Test for overall effect: $Z=0.19(P=0.85)$

2 Studies with exclusion of high-risk patients (ASA IV or V) Boerma 2002 $6 / 59$ Lau 2006

Total events: 22 (Wait-and-see), 0 (Prophylactic removal) Heterogeneity: $\mathrm{Chi}^{2}=0.27, \mathrm{df}=\mathrm{I}(\mathrm{P}=0.60) ; \mathrm{I}^{2}=0.0 \%$

Test for overall effect: $Z=2.99(P=0.0028)$

Total (95\% CI)

Total events: 34 (Wait-and-see), 14 (Prophylactic removal) Heterogeneity: $\mathrm{Chi}^{2}=10.65, \mathrm{df}=4(\mathrm{P}=0.03) ; \mathrm{I}^{2}=62 \%$

Test for overall effect: $Z=2.79(P=0.0053)$
$6 / 44$

$6 / 105$

$2 / 48$

197

$38.9 \%$

$39.7 \%$

$14.1 \%$

$92.7 \%$

$\rightarrow$

$0 / 49$

$0 / 82$

131

328

\section{7}

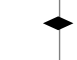

(

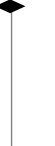

2

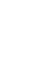

.

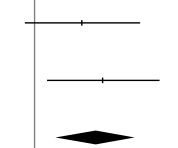

$3.8 \%$

$3.6 \%$

$7.3 \%$

$7.3 \%$

$100.0 \%$
$10.83[0.63,187.63]$

$30.43[1.86,499.28]$

$20.40[2.82,147.51]$

$2.36[1.29,4.32]$

$0.0010 .01 \quad 0.1 \quad 1 \quad 10 \quad 100 \quad 1000$

Favours wait-and-see Favours removal 
Analysis 3.8. Comparison 3 Stratified by patient ASA class, Outcome 8 Difficult cholecystectomy.

Review: Cholecystectomy deferral in patients with endoscopic sphincterotomy

Comparison: 3 Stratified by patient ASA class

Outcome: 8 Difficult cholecystectomy

Study or subgroup Wait-and-se $\mathrm{n} / \mathrm{N}$

I Studies with inclusion of high-risk patients (ASA IV or V)

Hammarstrom 1995

Suc 1998

Targarona 1996

Subtotal (95\% CI)

Total events: I (Wait-and-see), 0 (Prophylactic removal)

Heterogeneity: $\mathrm{Chi}^{2}=0.0, \mathrm{df}=0(\mathrm{P}=1.00) ; \mathrm{I}^{2}=0.0 \%$

Test for overall effect: $Z=0.75(P=0.45)$

2 Studies with exclusion of high-risk patients (ASA IV or V)

Boerma $2002 \quad$ 12/59

Lau 2006

$6 / 89$

148

Subtotal (95\% CI)

Total events: I8 (Wait-and-see), 25 (Prophylactic removal)
Heterogeneity: $\mathrm{Chi}^{2}=3.78, \mathrm{df}=|(\mathrm{P}=0.05):|^{2}=74 \%$

Test for overall effect: $Z=1.61(P=0.11)$

Total (95\% CI)

329

Total events: 19 (Wait-and-see), 25 (Prophylactic removal)

Heterogeneity: $\mathrm{Chi}^{2}=4.73, \mathrm{df}=2(\mathrm{P}=0.09) ; \mathrm{I}^{2}=58 \%$

Test for overall effect: $Z=1.40(P=0.16)$
Prophylactic removal

$\mathrm{n} / \mathrm{N}$

Risk Ratio M-H,Fixed, $95 \% \mathrm{Cl}$

Risk Ratio M-H,Fixed,95\% Cl

$3.38[0.14,80.52]$

$0.0[0.0,0.0]$

$0.0[0.0,0.0]$

$0 / 48$

194

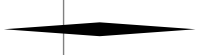

$3.38[0.14,80.52]$

I.II [0.5।, 2.4I ]

$0.35[0.14,0.84]$

0.63 [ 0.36, 1.10 ]

131

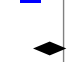

325

$0.68[0.39,1.17]$

A P P E D I C ES

Appendix I. Search Strategies

Favours wait-and-see Favours removal

\begin{tabular}{l|l|l}
\hline Database & Timespan of search & Search strategy \\
\hline $\begin{array}{l}\text { The Cochrane Hepato-Biliary Group Con- } \\
\text { trolled Trials Register }\end{array}$ & April 2007. & cholecystectom* AND sphincterotom* and choledocholithiasis \\
\hline
\end{tabular}


Cochrane Central Register of Controlled Issue 12007. Trials in The Cochrane Library

\#1 MeSH descriptor Cholecystectomy explode all trees in MeSH products $\# 2$ cholecystectom* in All Fields in all products \#3 (\#1 OR \#2)

\#4 MeSH descriptor Sphincterotomy, Endoscopic explode all trees in $\mathrm{MeSH}$ products

$\# 5$ sphincterotom* in All Fields in all products \#6 (\#4 OR \#5)

\#7 MeSH descriptor Choledocholithiasis explode all trees in $\mathrm{MeSH}$ products

\#8 Choledocholithiasis in All Fields in all products

\#9 (\#7 OR \#8)

\#10 (\#3 AND \#6 AND \#9)

MEDLINE (WinSPIRS 5.0)

MEDLINE (WINSPIRS 5.0$)$
1950 to April 2007.

\#1 explode "Cholecystectomy"/all subheadings

\#2 cholecystectom*

\#3 \#1 or \#2

\#4 explode "Sphincterotomy-Endoscopic"/all subheadings

\#5 sphincterotom*

\#6 \#4 or \#5

\#7 explode "Choledocholithiasis"/all subheadings

\#8 choledocholithiasis

\#9 \#7 or \#8

$\# 10 \# 3$ and \#6 and \#9

\#11 random* or blind* or placebo* or meta-analysis \#12 \#10 and \#11
1980 to April 2007.

\#1 explode "cholecystectomy"/all subheadings

\#2 cholecystectom*

\#3 \#1 or \#2

\#4 explode "sphincterotomy"/all subheadings

\#5 sphincterotom*

\#6 \#4 or \#5

\#7 explode "common-bile-duct-stone"/all subheadings

\#8 choledocholithiasis

\#9 \#7 or \#8

$\# 10 \# 3$ and \#6 and \#9

$\# 11$ random* or blind* or placebo* or meta-analysis

\#12 \#10 and \#11
Science Citation Index Expanded (http:// 1945 to April 2007. portal.isiknowledge.com/portal.cgi? DestApp=WOS\&Func=Frame)

\#1 12,359 TS=cholecystectom*
\#2 3,852 TS=sphincterotom*
\#3 1,788 TS=choledocholithiasis
\#4 409 \#3 AND \#2 AND \#1
\#5 >100,000 TS=(random* or blind* or placebo* or meta-anal-
ysis)
\#6 60 \#5 AND \#4




\section{WHAT'S NEW}

Last assessed as up-to-date: 27 July 2007.

24 September 2008 Amended Converted to new review format.

\section{H I S T O R Y}

Protocol first published: Issue 4, 2006

Review first published: Issue 4, 2007

\section{CONTRIBUTIONSOFAUTHORS}

V McAlister is responsible for correspondence. Search strategies were designed and run by Sarah Louse Klinkenberg, The Cochrane Hepato-Biliary Group Trials Search Co-ordinator, and they were approved by all authors. E Davenport searched the abstracts of Digestive Disease Week. V McAlister and E Renouf independently reviewed the search results for potential studies to be included. E Davenport and E Renouf assessed the trials and extracted data. Differences were resolved by V McAlister after discussion. V McAlister performed the analyses on RevMan 4.2. E Davenport and E Renouf reviewed the analyses. V McAlister wrote the first draft of the report . Revisions were suggested by E Davenport and E Renouf. All authors approved of the final review before submission.

\section{DECLARATIONSOF INTEREST}

V McAlister is a surgeon who performs endoscopic retrograde cholangio-pancreatography, common bile duct exploration, and cholecystectomy.

\section{SOURCES OF SUPPORT}

\section{Internal sources}

- No sources of support supplied

\section{External sources}

- Digestive Disease Foundation, USA. 


\section{INDEX TERMS}

\section{Medical Subject Headings (MeSH)}

*Cholecystectomy; *Sphincterotomy, Endoscopic; Choledocholithiasis [mortality; *surgery]; Randomized Controlled Trials as Topic

\section{MeSH check words}

Humans 